\title{
Bauxite Deposits of
}

Northwest Georgia

GEOLOGICAL SURVEY BULLETIN 1199-M 


\section{Bauxite Deposits of}

Northwest Georgia

By WALTER S. WHITE and NORMAN M. DENSON

With a section on the SUMMERVILLE AREA

By JOHN C. DUNLAP and ELIZABETH F. OVERSTREET

BAUXITE DEPOSITS OF THE SOUTHEASTERN UNITED STATES

G E O L O G I C A L

S U R V E Y

B U L L E T I N

$1199-\mathrm{M}$

Geology, history, and production

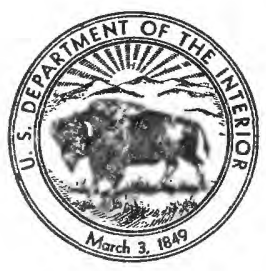


UNITED STATES DEPARTMENT OF THE INTERIOR

STEWART L. UDALL, Secretary

GEOLOGIGAL SURVEY

William T. Pecora, Director

For sale by the Superintendent of Documents, U.S. Government Printing Office Washington, D.C. 20402 


\section{CONTENTS}

Abstract
Previous work
General geology
Stratigraphy
Upper Cambrian and Lower Ordovician
Knox Group
Copper Ridge Dolomite
Chepultepec Dolomite

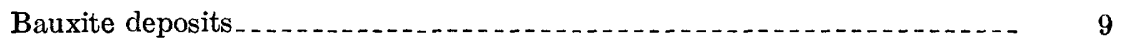

History, production, and reserves

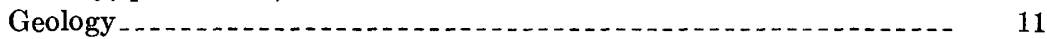

Shape and character.

Stratigraphic position...... 13

Structural position . .

Altitude _...

Topographic position 16

Relation to major landforms........................... 16

Proximity to brown iron ores.

Origin . . . . 19

Outlook for further discoveries. 20

Recommendations for exploration

Description of deposits. .

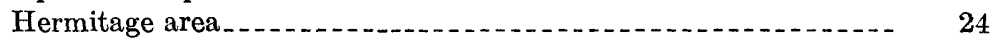

Section 3, district $5 \ldots$

Section 3, district $16 \ldots \ldots$

Section 3, district $23 \ldots \ldots \ldots$

Bobo area...

Section 3, district $22 \ldots \ldots$

Section 4, district 3...

Cave Spring area._.

Section 4, district 2 $2 \ldots$

Scattered deposits of southeastern Floyd and southwestern

Bartow Counties........... 31

Section 3, district $17 \ldots$

Section 3, district $22 \ldots \ldots \ldots$

Section 3, district 23... 
Bauxite deposits, Summerville area, Georgia, by J. C. Dunlap and E. F.

Overstreet

Page

General features.

Bauxite deposits ...

Taylor mine ........ 34

Shropshire deposit 1 $1 \ldots \ldots \ldots$

Shropshire deposit 2 .

Justice deposit_...

Hawkins mine....... 39

References cited

\section{ILLUSTRATIONS}

[Plates are in pocket]

Plate 1. Geologic map of the Hermitage area.

2. Geologic map of the Bobo area.

3. Geologic map of the Cave Spring area.

Figure 1. Map showing bauxite areas of part of the Northwest Georgia district. . . .

2. Map showing location and generalized geology of bauxite deposits in southeastern Floyd and southwestern Bartow Counties, $\mathrm{Ga}$

3. Geologic map of the Holland bauxite pits

4. Diagrammatic section of western part of the Hermitage area ... 17

5. Geologic map of the Summerville area and adjacent parts of

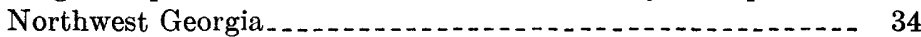

6. Map showing location of bauxite deposits at Summerville_..._. 35

7. Map of the Hawkins mine . . . . . . . . . . . . . . . . 40

\section{TABLES}

T 1. Geologic formations of the Northwest Georgia bauxite district

2. Production of bauxite, Northwest Georgia _............. 10

3. Altitudes of bauxite deposits . . 


\title{
BAUXITE DEPOSITS OF THE SOUTHEASTERN UNITED STATES
}

\section{BAUXITE DEPOSITS OF NORTHWEST GEORGIA}

\author{
By Walter S. White and Norman M. Denson
}

\begin{abstract}
Most of the bauxite deposits of Northwest Georgia are in the Hermitage, Bobo, and Cave Spring areas in Floyd, Bartow, and Polk Counties. The region has produced more than 400,000 tons of buxite from about 65 small mines, but the known reserves of high-grade bauxite are very small. The region was studied in 1942-43 as part of the strategic minerals program of the U.S. Geological Survey.

The rocks in the region include shale and quartzite of Cambrian age and dolomites of the Knox Group of Cambrian and Ordovician age. In the Hermitage area, a broad plateau underlain by nearly flat-lying strata of the Knox Group is interrupted by two anticlinal valleys, and the rocks are only slightly faulted. In the Bobo and Cave Spring areas, a series of reverse faults strikes nearly north and dips steeply east.

The bauxite occurs as pods or pockets in the residual clay derived from the dolomite of the Knox Group. Individual pockets are as much as 200 feet in width and at least 120 feet in depth. Most of them have roughly the shape of vertical cylinders or cones that taper downward; but a few resemble vertical veins, and others are blanket deposits. The bauxite is generally separated from the residual clay by an envelope of kaolinitic clay.

The deposits were probably formed in Eocene time, by weathering of transported clay that was deposited in or subsided into sinkholes.

Probably most of the deposits that crop out have been found. Undiscovered deposits should therefore be sought primarily in places where surficial debris is now accumulating rather than where it is being eroded. The following characteristics of the deposits themselves may be useful guides to areas favorable for new discovery.

1. All but one of the known deposits are within areas underlain by the Knox Group.

2. The deposits tend to lie along lines, some of which are known to be traces of faults. Lines that pass through several neighboring bauxite or iron-ore deposits, or follow faults, or are characterized by topographic features that suggest weakness of the underlying rocks may be regarded as favorable for prospecting.
\end{abstract}

3. The most favorable areas are above 800 feet in altitude.

4. In plateau areas, the dip-slope sides of high, cuestalike plateau rims are most favorable for the preservation of bauxite deposits. 
Areas that satisfy two or more of these conditions and are therefore regarded as favorable for exploration are so indicated on some of the geologic maps.

Five deposits of bauxite are known in the Summerville area. Two of these, the Taylor and Hawkins deposits, have been mined. Reserves of commercialgrade bauxite are negligible.

\section{INTRODUCTION}

The Hermitage, Bobo, and Cave Spring bauxite areas, once important producers of the ore of aluminum, include parts of Floyd, Bartow, and Polk Counties, Ga. Figure 1 shows the location of these areas and of an area east of the Bobo area and south of the Hermitage area that also contains a few deposits. Figure 2 and plates 1-3 are geologic maps of these areas. The only other bauxite area in Northwest Georgia is the Summerville area, discussed in a separate section of this report.

The Northwest Georgia bauxite district was studied in 1942 and early 1943 as part of the strategic minerals program of the U.S. Geological Survey. The immediate purpose of the study was to locate areas favorable for prospecting by the U.S. Bureau of Mines. Although a number of favorable areas were revealed, more promising possibilities in districts on the Atlantic Coastal Plain and in Arkansas made intensive exploration in Northwest Georgia less attractive. In 1943, a little hand augering was done on known prospects (Lewiecki, 1949), but none of the promising areas for wildcat exploration were tested.

The present report is based on unpublished data and field notes written during the 1940 's, and the writers have not restudied the area. A preliminary report was published in 1952 (White and Denson, 1952). Although the present report is out of date with respect to developments at certain deposits, this situation does not affect its primary purposenamely, to provide a guide to the known deposits of the district and to designate the areas that the writers consider most favorable for future exploration.

The investigation was carried out under the general direction of Josiah Bridge, who, with Preston E. Cloud, Jr., both of the Geological Survey, frequently joined the writers in the field in consultation on various problems. White spent 8 months in fieldwork, and Denson, about 10. James Morris assisted the writers for a month. White prepared the maps and report. Elizabeth F. Overstreet and M. M. Knechtel have made many helpful suggestions for improvement of the manuscript.

Thanks are due to many people for information on the location, character, and production of certain deposits. The following were particularly helpful: J. T. Watters, W. T. Watters, and Joe Lowrie of Hermitage; James Adams of Adairsville; Robert Mumford and 


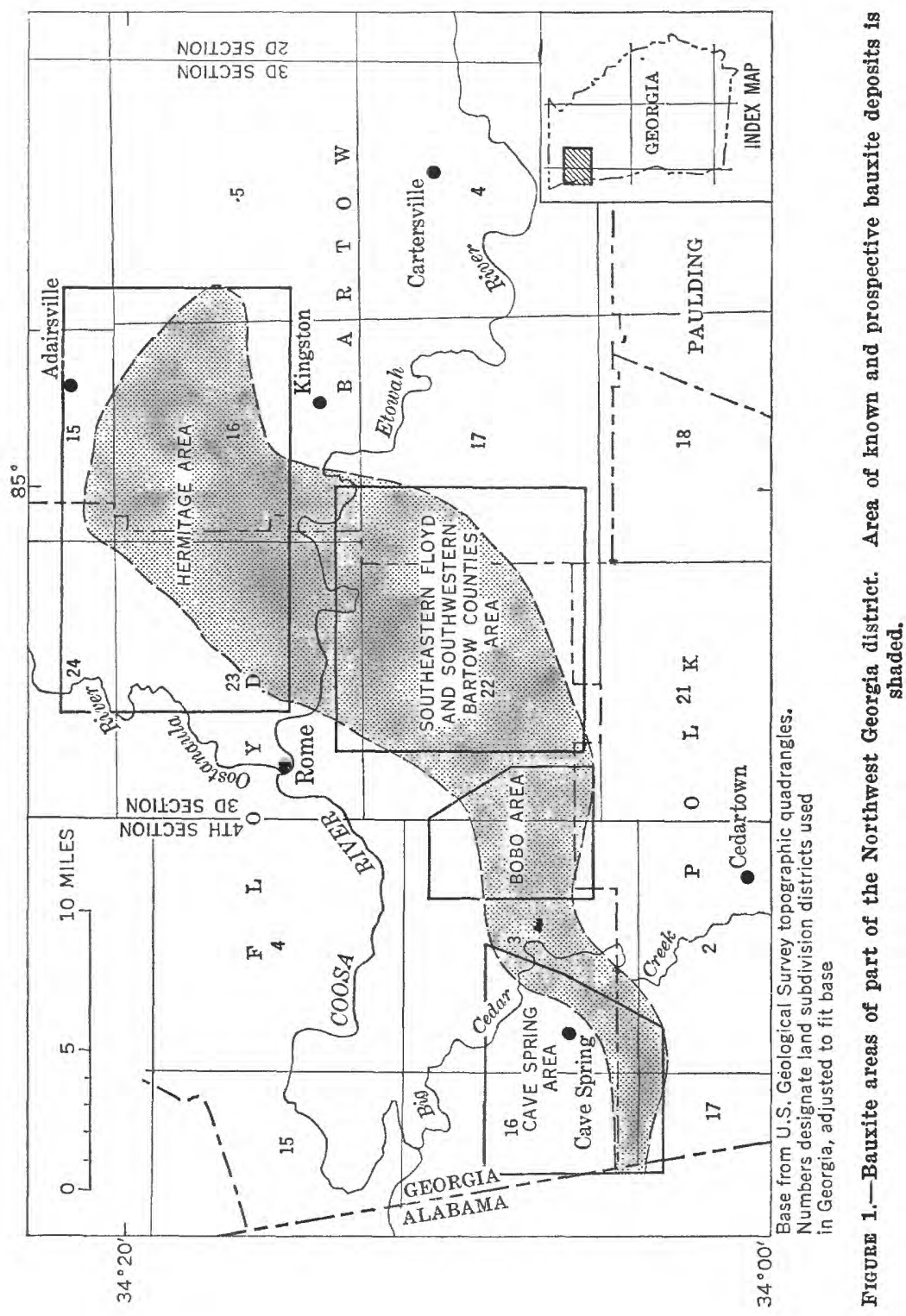




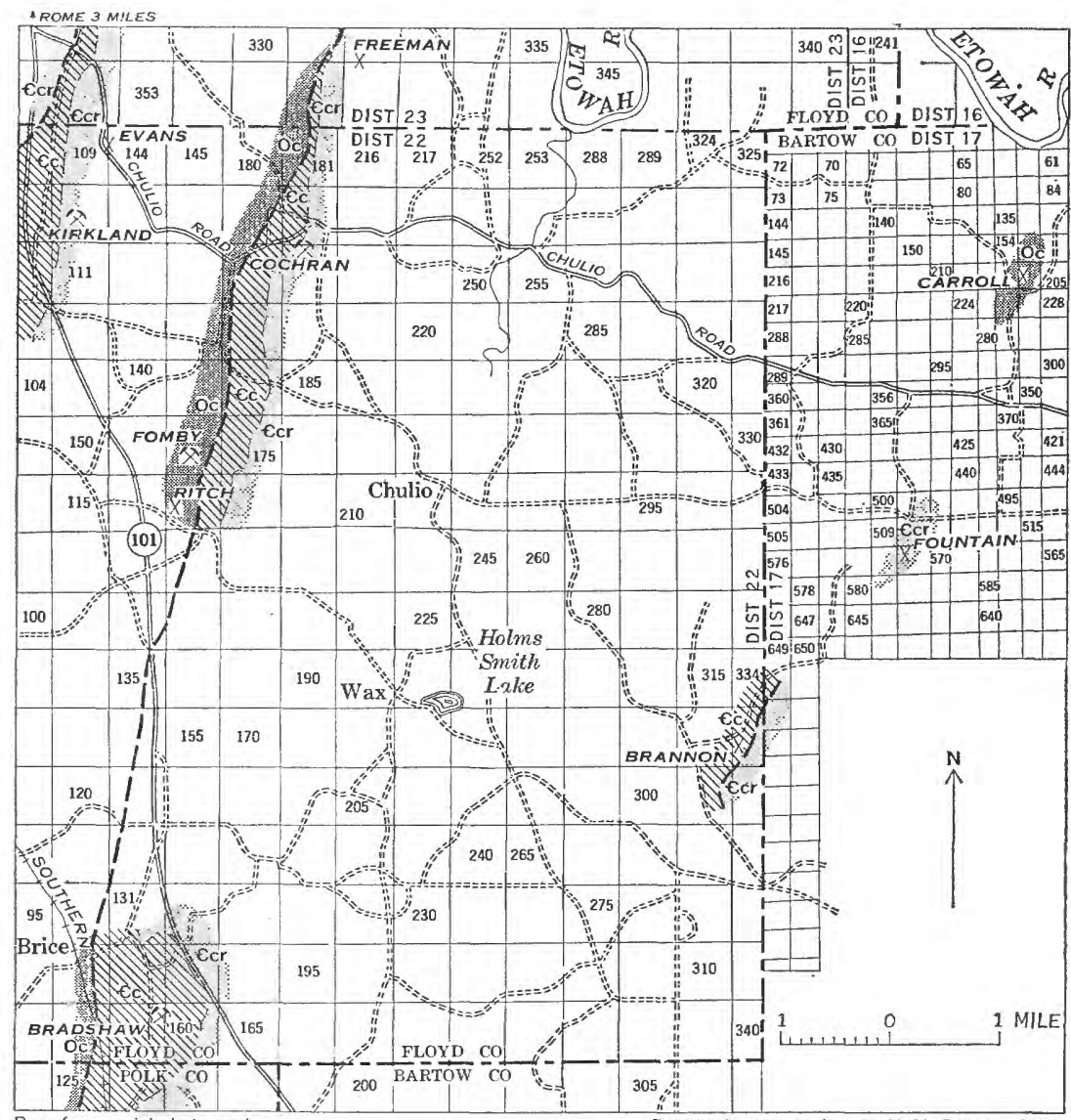

Base from aerial photographs

Reconnaissance geology by N. M. Denson, 1942

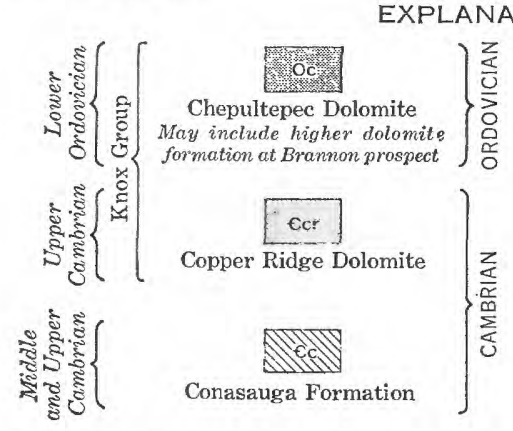

Contact, approximately located

Fault, approximately located

父

Bauxite mine

$x$

Bauxite prospect

FigURn 2.-Location and generalized geology of bauxite deposits in southeastern Floyd County and southwestern Bartow County, Ga. 
William Torbert of Cartersville; and J. Hebble of Rome. The writers are especially grateful to the former State Geologist, the late Garland Peyton, for his interest in the investigation and for placing file material of the Georgia Geological Survey at their disposal. A number of the deposits in the region were explored during the 1930's under the direction of the State Survey; the detailed records of this exploration have proved most helpful.

\section{PREVIOUS WORK}

Hayes $(1895,1902)$ and Watson (1904) have made the most complete studies of the geology and bauxite deposits of Northwest Georgia. Watson's report, in particular, has proved of great value for its detailed descriptions of many of the individual deposits. Many mines were active when Hayes and Watson studied the district, and they were able to see many more details of the occurrence of the bauxite than one can see today.

Others who have described the district or certain mines are Spencer (1893, p. 7-146 and 210-246), McCallie (1910, p. 39-49), Shearer (1917, p. 325-329), and Butts and Gildersleeve (1948, particularly p. 86-89).

\section{GENERAL GEOLOGY}

\section{STRATIGRAPHY}

The rocks that crop out in the Northwest Georgia bauxite district are sedimentary strata of Cambrian and Ordovician age that include dolomite, limestone, shale, and quartzite. The stratigraphic units into which the sequence of these strata has been divided are shown in table 1. With one exception, the bauxite deposits are found only in areas underlain by rocks of the Knox Group, so only formations in this group are described in the following paragraphs. The Conasauga and Rome Formations and the Weisner Quartzite, however, do appear on geologic maps accompanying this report.

\section{UPPER CAMBRIAN AND LOWER ORDOVICIAN}

\section{KNOX GROUP}

As exposed in Northwest Georgia, the Knox Group (Butts and Gildersleeve, 1948, p. 16-18) comprises two formations: the Copper Ridge Dolomite (Upper Cambrian) and the Chepultepec Dolomite (Lower Ordovician). Areas in which dolomitic rock of these two formations crops out are largely occupied by thick deposits of residual material, consisting chiefly of clay. The unweathered rocks of both formations are nearly everywhere concealed by the residuum, and fewer than 20 exposures of fresh dolomite of the Knox Group were 
seen by the writers during their study. Where the bedrock is thus concealed, mapping of the two formations is based largely on the areal distribution, in the residual material, of fragments of chert and sandstone that contain diagnostic fossils or possess other distinctive characteristics.

The absence of adequate data on the thickness of the residual clay at most places and on the amount of compaction that takes place on removal of carbonate minerals makes it difficult to estimate the actual thicknesses of the subdivisions of the Knox Group. The volume ratio of original dolomite to residual clay may well be more than 10 to 1 on the basis of the amount of impurity in the dolomite (see analyses in Watson, 1904, p. 35), and the residual clay is at least 50 or 60 feet thick in many high banks and roadcuts in the region. The traces of geologic boundaries in the Hermitage area (pl. 1) indicate that the dip in most places is rather gentle. With no allowance for compaction and subsidence, one may estimate that fossils of the Chepultepec Dolo-

TABLE 1.-Geologic formations of the Northwest Georgia bauxite district

[Thickness: Given by Butts in "Geologic map of Northwest Georgia" by Butts and Gildersleeve (1948)]

\begin{tabular}{|c|c|c|c|c|}
\hline Age & & Formation & $\underset{\text { (feet) }}{\text { Thickness }}$ & Lithology \\
\hline$\underset{\text { Early }}{\text { Ordovician }}$ & \multirow{2}{*}{ 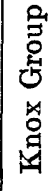 } & \multirow{2}{*}{$\begin{array}{c}\begin{array}{c}\text { Chepultepec } \\
\text { Dolomite }\end{array} \\
\begin{array}{c}\text { Copper Ridge } \\
\text { Dolomite }\end{array}\end{array}$} & 500 & Dolomite. \\
\hline $\begin{array}{c}\text { Late } \\
\text { Cambrian }\end{array}$ & & & 2,000 & Dolomite. \\
\hline $\begin{array}{c}\text { Middle and } \\
\text { Late } \\
\text { Cambrian }\end{array}$ & & $\begin{array}{l}\text { Conasauga } \\
\text { Formation }\end{array}$ & 2,000 & $\begin{array}{l}\text { Dominantly soft thinly lami- } \\
\text { nated buff-colored shale, with } \\
\text { beds and lenses of limestone. } \\
\text { Minor dolomite near top. } \\
\text { Thick shale members distin- } \\
\text { guished in pl. } 1 \text {. }\end{array}$ \\
\hline $\begin{array}{l}\text { Early } \\
\text { Cambrian }\end{array}$ & & $\begin{array}{l}\text { Rome } \\
\text { Formation }\end{array}$ & 2,000 & $\begin{array}{l}\text { Red and green shale and sand- } \\
\text { stone. }\end{array}$ \\
\hline $\begin{array}{c}\text { Early } \\
\text { Cambrian }\end{array}$ & & $\begin{array}{l}\text { Shady } \\
\text { Dolomite (?) }\end{array}$ & (?) & \\
\hline $\begin{array}{c}\text { Early } \\
\text { Cambrian }\end{array}$ & & $\begin{array}{l}\text { Weisner } \\
\text { Quartzite }\end{array}$ & 2,000 & $\begin{array}{l}\text { Quartzite and quartzitic con- } \\
\text { glomerate, minor shale. }\end{array}$ \\
\hline
\end{tabular}

1 The Shady Dolomite has been mapped in nearby areas but was not recognized in the Northwest Georgia bauxite district. 
mite on a hilltop $11 / 2$ miles southwest of Halls Station are 500 to 600 feet stratigraphically above the top of the Conasauga Formation and that the basal zone of abundant sandstone is generally 250 to 300 feet above the Conasauga. The true stratigraphic intervals must be somewhat greater.

COPPER RIDGE DOLOMITE

The stratigraphy of the Copper Ridge Dolomite and overlying strata is discussed here in terms of residual materials because the only characteristics that can be used in geologic mapping are those of the residuum.

At the base of the Copper Ridge Dolomite, in contact with shale that forms the top of the Conasauga Formation, there is generally a zone composed largely of dense massive chert that breaks out in large fragments. Porous chert that is restricted to the top of this zone also yields abundant fragments, typically on steep slopes at altitudes 50 to 150 feet above the nearest shale of the Conasauga Formation. Some of this porous chert is spongelike. Dark-gray chert with cavities resembling large wormholes scattered through it is common, and some chert contains fossils of Copper Ridge age. Above the zone of porous chert is a zone more than 200 feet thick in which the chert is of various types, though none of these are particularly distinctive or characteristic.

Though the contact between the massive chert zone and the underlying shale is regarded by the authors as the actual base of the Copper Ridge Dolomite, the shale is so poorly exposed in much of the bauxite district that this contact cannot be accurately or consistently mapped. In the Bobo and Cave Spring bauxite areas and in the bauxite area shown on figure 2, therefore, the bottom of the zone of porous chert has been arbitrarily mapped in lieu of the actual base of the Copper Ridge Dolomite. In these bauxite areas this zone can be traced rather readily and with fair reliability by observing the distribution of float derived from it; it yields a map pattern, moreover, that is consistent with the gentle southeastward dip of the bedding as expressed in the topography. In the Hermitage area (pl. 1), however, where the slopes are generally steeper than in the other three areas, strata at and near the top of the Conasauga are commonly exposed on gullied hillsides, and in that area the base of the Copper Ridge is mapped at or close to its actual position, which is considered to be just above the uppermost bed of shale.

\section{CHEPULTEPEC DOLOMITE}

Resting on the chert-bearing strata that are assigned to the upper part of the Copper Ridge Dolomite is a zone that has been assigned to the Chepultepec Dolomite. This zone, which seems to be a few 
tens of feet thick, is characterized by float consisting of plates or slabs of indurated sandstone that range from an inch to about a foot in thickness. The sandstone does not crop out even where it sheds abundant float; probably it is interbedded with dolomite and breaks up readily as the dolomite dissolves. The boundary between the Copper Ridge and Chepultepec Dolomites has here been placed arbitrarily at the base of the zone of sandstone. This zone, which generally seems to be about half way between fossiliferous rocks of each formation, is a useful and satisfactory marker for mapping purposes, though more precise paleontologic zoning may some day make it necessary to place the boundary higher or lower. The sandstone zone is present in all parts of the district that are underlain by the Chepultepec and seems to be nearly continuous, notwithstanding small gaps in the continuity of the float in some places and its scarcity at several others. With due allowance for the vagaries of float in general, such irregularities in distribution might, perhaps, be expected, even of float derived from a perfectly continuous stratigraphic unit.

The sandstone zone is overlain by at least 250 feet of dolomitic strata containing chert without distinctive characteristics; in that respect the strata resemble those below the sandstone that are assigned to the upper part of the Copper Ridge Dolomite. Abundant black to white dense chert concretions shaped like pancakes occur locally in the dolomite above the sandstone, but even these do not serve for identification of these strata, inasmuch as virtually identical concretions are present locally in the beds below the sandstone.

Porous chert containing fossils characteristic of the Chepultepec Dolomite is present locally at least 250 feet stratigraphically above the sandstone zone; this is a minimum distance, without allowance for slump and for the great amount of compaction that must have taken place during development of the residual clay in which the chert now occurs.

\section{STRUCTURE}

The structure of most of the district is simple. In the Hermitage area (pl. 1), the rocks are nearly flat. A broad plateau upheld by strata of the Knox Group is interrupted by two broad low anticlines that bring the Conasauga Formation to the surface in the north-south valley of Barnsley Creek and the larger valley of Oothkalooga and Connesena Creeks that extends south from Adairsville. The latter anticline is locally bounded by a fault along its west side. Small inliers of the Conasauga a mile east of Hermitage reflect a minor upwarp. The rocks of the Hermitage area are cut by two sets of small faults that have been mapped on the basis of apparent stratigraphic offset. One set strikes north to northeast and probably dips steeply 
eastward. The east side of each fault has risen with respect to the west. Faults of the second set strike roughly at right angles to those of the first, and probably are essentially vertical. They have no uniform direction of offset.

The remainder of the bauxite district (pls. 2,3 ; fig. 2 ) is characterized by a series of fault blocks. The individual blocks strike north to north-northeast and range from a half mile to several miles in width. The bedding in the blocks dips gently to fairly steeply east or southeast. Each block seems to be bounded on the west by a reverse fault that raises it several hundred feet stratigraphically with respect to the next block to the west. Erosion has carved valleys in the shales and left long parallel ridges in the intervening areas that are underlain by the Knox Group.

Small klippen of Weisner Quartzite in the southwestern part of the Cave Spring area (pl. 3) are outliers of the overthrust mass of Indian Mountain, which lies just south of the map (Hayes, 1902).

There is no good evidence, within the areas mapped, for the actual dip of any fault except the thrust fault beneath these klippen. None of the faults shown on plates 1-3 and figure 2 can be viewed in outcrop. Furthermore, the fault traces cannot be located with enough precision to distinguish, by means of topographic expression, between a vertical fault and a fault dipping as little as $30^{\circ}$.

\section{BAUXITE DEPOSITS}

\section{HISTORY, PRODUCTION, AND RESERVES}

The first material identified as bauxite in the United States was found two miles east of Hermitage (pl. 1) about 1883; the discovery was announced in 1887. Mining of bauxite began the following year, and Georgia was the leading producer until 1892, when Alabama took the lead. Since the first substantial production of bauxite in Arkansas in 1903, the Northwest Georgia district has contributed only a small fraction of the Nation's total. The pockety nature of the deposits and irregular marketing conditions have caused large fluctuations in the annual production. Most of the bauxite has been used in the manufacture of chemicals.

The total amount of bauxite that has been mined in Northwest Georgia is not recorded. The production was reported annually from 1889 to 1900 , but since 1900 , separate figures have been published only for the years 1902, 1904, 1909, 1910, and 1917. This record, though incomplete, can be used to estimate the order of magnitude of the total production. The available data are shown in table 2. 
TABLE 2.-Production of bauxite, Northwest Georgia

\begin{tabular}{|c|c|c|}
\hline Year & $\begin{array}{c}\text { Bauxite } \\
\text { (long tons) }\end{array}$ & Source of data \\
\hline $\begin{array}{l}1889 \\
1890 \\
1892 \\
1893 \\
1894 \\
189\end{array}$ & $\begin{array}{r}728 \\
1,844 \\
3,301 \\
5,110 \\
2,415 \\
2,050 \\
3,756 \\
7,313 \\
7,507 \\
12,943 \\
19,619 \\
20,715 \\
19,000 \\
16,909 \\
20,000 \\
223,579 \\
15,000 \\
0\end{array}$ & $\begin{array}{l}\text { Phalen }(1911, \text { p. } 713) \\
\text { Do. } \\
\text { Do. } \\
\text { Do. } \\
\text { Do. } \\
\text { Do. } \\
\text { Do. } \\
\text { Do. } \\
\text { Do. } \\
\text { Ingalls }(1906, \text { p. 46) } \\
\text { Do. } \\
\text { Do. } \\
\text { Do. } \\
\text { Do. } \\
\text { Phalen }(1911, \text { p. } 713) \\
\text { Morse }(1923, \text { p. } 78) \\
\text { Hill (1921, p. 5) } \\
\text { Julihn }(1933, \text { p. } 155)\end{array}$ \\
\hline
\end{tabular}

1 Production in 1910 is stated to be 16 percent more than in 1909 . Figure obtained by calculation from 1910 estimate.

2 Includes first shipments from Coastal Plain, probably very small.

In the 5 years between 1900 and 1910, inclusive, for which figures are given in the table, the bauxite mined in Northwest Georgia was 82.6 percent, on the average, of the combined total for Georgia and Alabama as given by Ingalls (1906, p. 46) for 1900 and by Phalen (1916, p. 183) for the other years. If we assume that Northwest Georgia produced the same proportion of the total throughout the period, an average of about 18,800 long tons of bauxite per year was mined from 1900 to 1910, inclusive. Total production from 1889 through 1909 is thus estimated to be about 250,000 long tons of bauxite.

Deposits in the Coastal Plain in Georgia increased in importance after 1910, and only the total Georgia production has been published for the years 1910 to 1928 (Franke and Trought, 1939, p. 636). If we assume that production from Northwest Georgia decreased uniformly from about 100 percent of the State production in 1910 to 28 percent in 1917 and to none in 1930, the total production from the northwest district for the period 1910 to 1929 was approximately 150,000 tons. The total production of bauxite from 1889 to 1929 was therefore about 400,000 tons. Production between 1930 and the time of our field work (1943) was small.

The 400,000 tons thus estimated for the total production of the Northwest Georgia district is of the same order of magnitude as an estimate of slightly less than 500,000 tons that the writers made on the basis of the size of the pits and dumps. According to the latter estimate, 
about 45 percent of the total came from three large mines- the Julia, Watters, and Booger Hollow mines. More than 20 percent came from five of the Holland group of pits (pl.1). About 15 percent came from the Hampton, Curtis, Terry-Shaw, Maddox, Hawkins, and Fat John mines; and the remaining 20 percent, from about 50 small mines, including a few small mines in the Summerville area outside the areas described here.

Known reserves of high-grade bauxite are very small and consist mostly of ore left in the bottoms of abandoned mines. Their recovery would be costly because of slumped walls of pits. The amount of very low grade siliceous and ferruginous bauxite and bauxitic clay adjacent to old mines and in unworked prospects may exceed 300,000 tons.

\section{GEOLOGY}

The character of the bauxite deposits and of the materials within and surrounding them has been described in considerable detail by Hayes (1895, p. 551-597) and Watson (1904). The following brief account of the geology of the deposits emphasizes those characteristics that seem to bear most closely on the problem of prospecting for new deposits, and the reader is referred to the reports of Hayes and Watson for additional information on the chemical composition of the bauxite and associated materials and on the textural varieties of the bauxite. Veatch (1909, p. 261-274) described those features of the bauxite and associated clays that have a bearing on the clay industry.

\section{SHAPE AND CHARACTER}

The bauxite occurs in pockets in the residual clay and chert derived from the weathering of the underlying dolomitic rocks. The pockets range from a few feet to at least 200 feet in width and from a few feet to 120 feet in depth. Most of the bauxite deposits seem to be oval or circular in plan (fig. 3) with vertical walls or with walls that dip steeply inward like those of a funnel.

Less commonly, the deposits resemble steeply dipping or vertical veins. This type, best exemplified by the Curtis and Conneseena deposits (pl. 1), may be several hundred yards long. These veinlike deposits generally consist of a row of individual pods or lenses, each elongate parallel to the line of the whole, and do not represent a single continuous mass of bauxite. The pods range in width from a few feet to 50 feet or more, and there may or may not be a connecting mass of bauxite between adjacent pods.

A few deposits-like the Terry-Shaw, Mary, and Henry-seem to be more like blankets and have far greater horizontal extent than their 


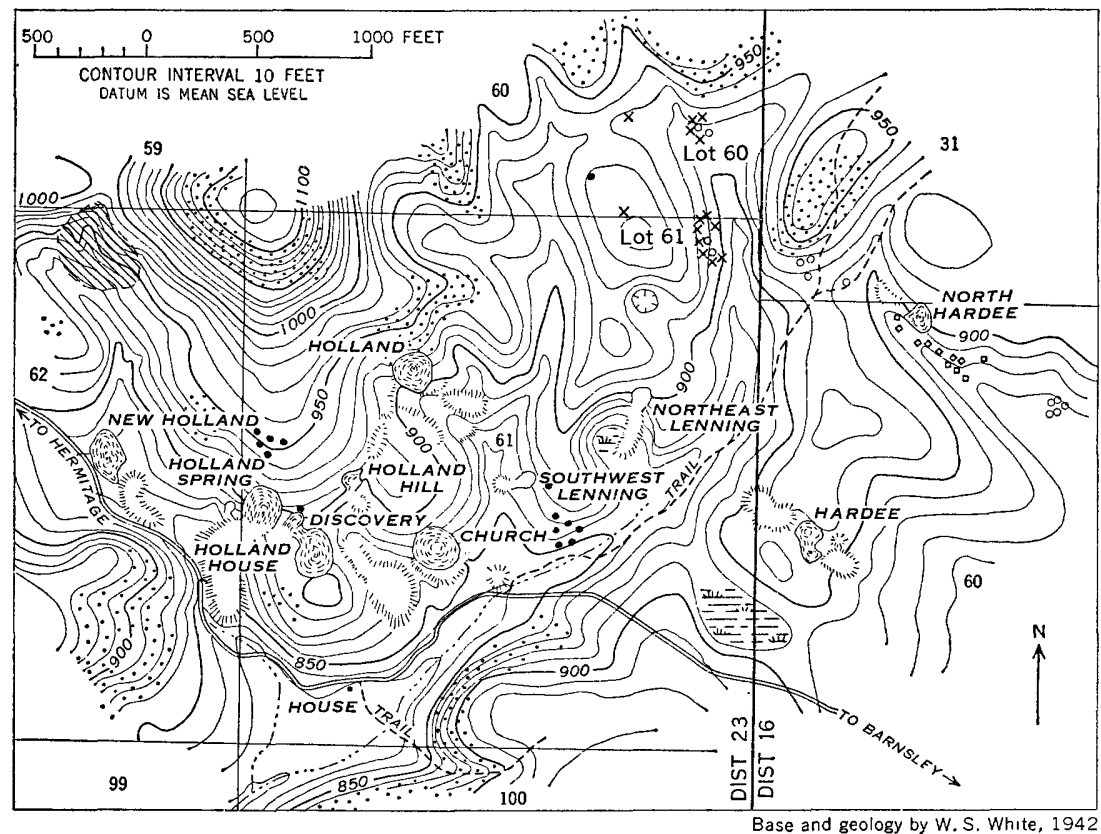

Base and geology by W.S. White, 1942

EXPLANATION

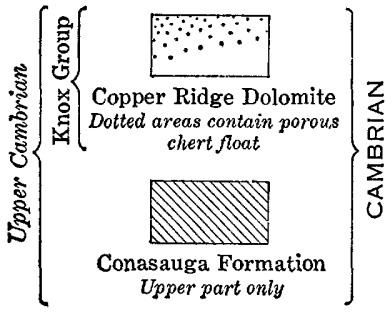

Contact, approximately located

\section{庳}

Bauxite mine

Test hole in bauxite

Test hole that may be in bauxite
Test hole in residual clay

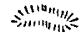

Mine dump

$\because \because$

Brown iron ore (outcrop)

61

Land lot number Lot lines approximate

Figdre 3.-Geologic map of the Holland bauxite pits, Floyd County, Ga.

probable thickness. Such deposits may show a layering of the bauxitic material, or of bauxite and clay, and this layering generally dips in the direction of the present topographic slope.

The residual clay in which the bauxite deposits occur is typically buff, gray, or pinkish clay containing sparse to abundant chert fragments. The clay fraction "contains large amounts of illite, montmorillonite, and mixed-layer clay minerals, as well as kaolinite" (Overstreet, 1964, p. A14).

So far as can be seen in the present poor exposures, the bauxite typically is separated from the surrounding residual clay by an envelope of chert-free plastic clay which probably is kaolinitic nearly everywhere (Watson, 1904, p. 38-40; Veatch, 1909, p. 261-262; Bridge, 
1950, p. 186-191). X-ray analyses of these clays have shown kaolinite and locally halloysite to be the only clay minerals present (Overstreet, 1964). They will be referred to in this report as kaolinitic clay, rather than kaolin, because of a variable amount of impurities, chiefly iron oxides. Bauxite is rarely seen in direct contact with cherty residual clay in pit walls. In the veinlike Curtis deposit, the bauxite seems to lie in the centers of large pods of kaolinitic clay; where the vein is wide, kaolinitic clay forms an envelope around the bauxite, and in at least one place, where the vein is narrow, the vein consists entirely of clay. In addition to an envelope of kaolinitic clay, most deposits also contain many veins and horses of clay within the bauxite mass itself (Watson, 1904, p. 38 and p. 60-118; Veatch, 1909, p. 262).

The bauxite deposits and their envelopes of kaolinitic clay are generally covered by several feet of detrital clay and chert that have washed or slumped down over them. As most of the deposits have been discovered from bauxite outcrops or float, it may be presumed that the hard bauxite commonly protrudes through this cover in places or breaks off in pieces that become incorporated with the surface debris.

\section{STRATIGRAPHIC POSITION}

With the exception of the Bradshaw deposit (fig. 2), which seems to be in an area underlain by the Conasauga Formation, all the deposits lie within or so close to areas underlain by the dolomite of the Knox Group that all formations other than those of the Knox Group may well be ignored in the search for new deposits. No particular stratigraphic interval or intervals within the Knox Group seem to be notably more favorable for the occurrence of bauxite deposits than any other.

\section{STRUCTURAL POSITION}

Many of the deposits in the region show a remarkable tendency to be on lines that pass through three or more adjacent deposits. Such alinements are conspicuous in the southwestern part of the Bobo area (pl. 2) and in the area 1 to 2 miles due south of Hermitage (pl. 1); less striking examples can be found in many other places. The more notably veinlike deposits represent an extreme manifestation of alinement. As noted by Hayes $(1895$, p. 577$)$, some of these line are parallel to and on, or very close to, known faults, a relation best shown in the Bobo area (pl. 2). The detailed mapping done in connection with the present investigation shows a similar coincidence of faults with lines of bauxite deposits in parts of the Hermitage area (pl. 1).

For the following reasons the writers conclude that the loci of most of the known bauxite deposits are along faults: Many deposits have been mapped along or immediately adjacent to known faults; some 
deposits have a notably veinlike form; at many places three or more deposits are conspicuously alined. Faults are not shown on the maps, however, except where there is evidence of stratigraphic offset; a large number of faults may have been missed because of the uncertainties of mapping in residual materials.

\section{ALTITUDE}

The altitudes of the tops of most of the deposits were carefully determined with an altimeter in areas not covered by accurate topographic maps. These altitudes are given in the descriptions of individual deposits. The deposits range from 645 to 1,110 feet above sea level. The median and average altitudes are about 885 feet; 50 percent of the deposits lie between 835 and 935 feet above sea level, and 90 percent, between 770 and 1,000 feet. Data for the various districts are tabulated in table 3. The median altitudes show the most uniform trend, a gradual descent from northeast to southwest. This trend may have little meaning, however, as the median altitude of the deposits in the Rock Run area, Alabama, immediately southwest of the Cave Spring area, is well over 900 feet.

The high frequency of occurrence of deposits close to 900 feet above sea level has been held by Hayes (1895), Watson (1904, p. 28), and others, and most recently by Bridge (1950, p. 191-193), to reflect a relationship to an Eocene land surface whose temporary base lay, in this region, close to 950 feet above the present sea level. Discovery of Eocene fossils in lignite in the Booger Hollow deposit (Bridge, 1950, p. 194) suggests a correlation with the Eocene deposits of the Coastal Plain. The present wide range in altitude of the deposits, 645 to 1,110 feet, is attributed to deposition of the bauxite, or its parent material, in Eocene sinkholes, or to subsidence of the bauxite into sinkholes at some time since the Eocene (Bridge, 1950, p. 197). Bridge (1950, p.

TaBLe 3.-Altitudes of bauxite deposits, in feet

\begin{tabular}{|c|c|c|c|c|c|c|}
\hline Area & Highest & Median & Lowest & $\begin{array}{c}25 \text { percent } \\
\text { of deposits } \\
\text { are } \\
\text { above- }\end{array}$ & $\begin{array}{l}25 \text { percent } \\
\text { of deposits } \\
\text { are } \\
\text { below- }\end{array}$ & A verage \\
\hline $\begin{array}{l}\text { Hermitage, southeast of } \\
\text { Adairsville }\end{array}$ & 1,050 & 935 & 865 & 990 & 915 & 949 \\
\hline $\begin{array}{l}\text { Hermitage, southwest of } \\
\text { Adairsville }\end{array}$ & 1,110 & 910 & 695 & 970 & 840 & 906 \\
\hline Southeastern Floyd and south- & & & & & & \\
\hline $\begin{array}{l}\text { western Bartow Counties. } \\
\text { Bobo }\end{array}$ & 920 & $\begin{array}{l}885 \\
860\end{array}$ & $\begin{array}{l}645 \\
785\end{array}$ & $\begin{array}{l}900 \\
900\end{array}$ & $\begin{array}{l}850 \\
835\end{array}$ & $\begin{array}{l}851 \\
866\end{array}$ \\
\hline Cave Spring ..... & 945 & 855 & 750 & 920 & 815 & 861 \\
\hline All areas combined. & 1,110 & 885 & 645 & 935 & 835 & 886 \\
\hline
\end{tabular}


196-197) suggested, specifically, that kaolin or other material, formed by weathering of crystalline rocks of the Piedmont and Blue Ridge, was transported into the Appalachian Valley and there deposited in sinkholes on the so-called Harrisburg peneplain.

Bridge's theory must be modified in order to explain the large number of deposits that lie well above the so-called Harrisburg peneplain if the kaolinitic material was indeed carried by streams from the Piedmont or Blue Ridge. Of 168 deposits for which altitudes were measured, 12 mines and 19 prospects are higher than 950 feet, and 8 mines and 7 prospects are above 1,000 feet. The streams that transported the kaolin of these deposits must have had beds considerably higher than 950 feet (present altitude), and at least one of them must have had a bed above 1,100 feet. If these were also major streams, which they would have to be in order to have their headwaters in the crystalline areas to the east, it is unlikely that they would be flowing in channels 100 to 150 feet above the local base level. Either base level was considerably higher than 950 feet when the kaolin was transported, or the kaolin is of fairly local derivation.

The writers believe that the deposits formed close to a surface of moderate relief, the lowest points of which lay well above the bottoms of the modern valleys. The original range in altitude of the tops of deposits need not have been large. The present wide range in altitude is attributed largely to slump during erosion and karst formation. According to this reasoning, the number of deposits above 1,050 feet is small primarily because the total land surface now remaining above this altitude is small. The number of deposits below 750 feet is believed to be small because relatively few deposits can survive this amount of erosional lowering of the land surface. The average altitude of 885 feet, empirically, would seem to represent a peak frequency resulting from opposing action of these two factors.

The number of deposits in any given range of altitudes should be divided by the area of land surface within this range of altitudes to provide a meaningful measure of the frequency of deposits in relation to altitude. This quotient, the number of deposits per unit area within a given range of altitudes, should decrease from a maximum for areas above 1,100 feet of altitude to a very small value for areas below 700 feet, if the writers' view is correct. Brief inspection of the old smallscale topographic maps is sufficient to show that the number of deposits per unit area decreases rapidly below 800 feet, but more detailed topographic maps are needed for most of the region before the concentration at higher altitudes can be determined. In the eastern part of the Hermitage area, for which a detailed topographic map (Adairsville quad.) is available, the number of deposits per unit area seems to 
be fairly constant for various altitudes above 800 feet; a larger sample is needed, however, before one can obtain reliable figures for the number of deposits per unit area over the whole range of altitudes involved.

\section{TOPOGRAPHIC POSITION}

Bauxite deposits are found in all conceivable topographic positions, from the tops of hills and ridges to the bottoms of broad valleys. A majority lie in places that suggest weakness of the underlying rocks, such as saddles, the inner edges of benches, the base of steep slopes, and forks in ravines.

\section{RFLATION TO MAJOR LANDFORMS}

In the Hermitage area (pl. 1), most of the deposits lie on the dip slope of the high cuestalike ridges that border the dolomite plateaus. Large deposits are most commonly found at altitudes 50 to 150 feet below the level of the crestline and at distances of a quarter of a mile to a mile from the crest. This empirical correlation with major landforms might reflect either conditions of origin or conditions that lead to the preservation of bauxite deposits. As the bauxite itself is ancient and was probably formed on or near a surface of relatively low relief, present major topographic features are probably related only remotely, if at all, to features that existed at the time of origin of the deposits. The intensity and kind of erosion that has sculptured the present topography, however, must have profoundly influenced the chances of preservation of deposits.

Figure 4 is an attempt to show diagrammatically how bauxite deposits may have come to be concentrated near the elevated plateau rims of the Hermitage area. If the land at any place has been lowered entirely by solution of dolomite since Eocene time, any insoluble material present on the Eocene surface should still be present on the modern surface. The thickness of the residual mantle at such a place should be approximately equal to the thickness of the mantle in Eocene time plus one-tenth of the thickness of the dolomite that has been removed by solution since Eocene time if we assume there is 10 percent insoluble material in the dolomite. The dotted line of figure 4 represents the locus, in Eocene time, of insoluble particles in the dolomite that now lie at the surface of the land. In places where the lowering of the land has taken place entirely by solution of carbonates, this dotted line coincides with the Eocene surface.

Where surface erosion has been the most important agent in lowering the land, on the other hand, the older Eocene and pre-Eocene residuum would have been largely stripped away, and the present mantle in such places, would be thin and of relatively recent origin. In areas 


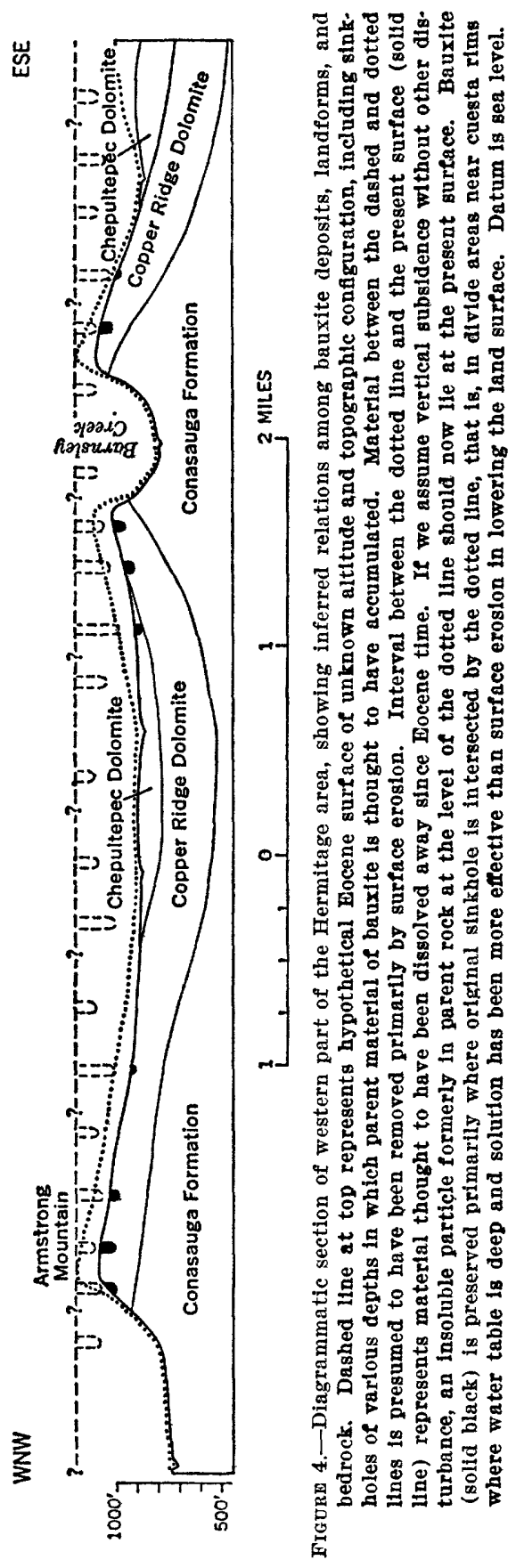


where surface erosion has been effective, the dotted line of figure 4 lies at or just above the present land surface.

The dotted line of figure 4 is shown far above the present surface near the cuestalike plateau rims and close to the present surface in stream valleys both in the slightly depressed central parts of the plateau and in the valleys where the Conasauga Formation is exposed. The water table is presumed to be generally deepest in the present divide areas near the plateau rims. To the extent that a deep water table would favor solution-the formation of caves and sinks and thus subterranean drainage at the expense of surface drainage-the role of solution should be greatest in these divide areas, and the dotted line, therefore, highest above the present surface.

Inasmuch as everything that was above the dotted line of figure 4 in Eocene time has been removed by erosion, bauxite occupying an Eocene sinkhole should, under ideal circumstances, be preserved only if the bottom of the sinkhole was below the dotted line. Because the land surface is highest at the plateau margins and because, in addition, the dotted line is presumed to be farthest above the present land surface in these areas, a random distribution of Eocene sinkhole deposits of various depths would tend to result in a modern concentration in these plateau margins, where deposits appear actually to be most abundant.

The explanation offered here would be immeasurably strengthened by a demonstration that the areas in which bauxite is found are, indeed, most commonly areas of thicker than average residuum, but unfortunately no critical data are readily available on the depth of overburden. Even if this explanation is generally correct, some exceptional conditions or characteristics may locally preserve deposits in places that would theoretically be regarded as unfavorable. For example, a few unusual deposits, such as at the Hawkins mine, lie at low altitudes far removed from the plateau rims.

One other type of area in addition to the dip slopes of plateau rims might be favorable for the occurrence of bauxite. The plateau rims are commonly major drainage divides, but here and there major divides also cross the plateaus. The land surface in these headwater areas well within the plateaus is gently rolling upland, considerably less dissected than even the dip slopes of the cuesta rims. Active sinkholes are not abundant, but broad, relatively flat swales are common. In many places the clay exposed at the surface is considerably redder and more free from chert than normal. In these areas, as in those closer to the plateau rims, solution may well have been more important than surface erosion in reducing the land surface, and chances for preservation of an Eocene bauxite deposit would, therefore, be good. By the same 
token, a deposit so preserved would also very likely remain concealed. Whether deposits actually exist in areas of this type remains to be demonstrated by physical exploration; some areas in which a test might be carried out are suggested in the section "Recommendations for exploration."

In most of the Bobo and Cave Spring areas (pls. 2 and 3) the rocks dip relatively steeply, and the ridges are hogbacks rather than cuestas. There are few prominent scarps like those of the Hermitage district, and both sides of most ridges have comparable slopes; these slopes are generally shorter and much less steep than the scarps of the Hermitage district. The bauxite deposits lie on the flanks and tops of the hogback ridges and on the floors of the intervening valleys. If regional geomorphologic controls exist, they were not detected.

\section{PROXIMITY TO BROWN IRON ORES}

Proximity to deposits of brown iron ore is characteristic of bauxite deposits. This is strikingly shown on the "Economic Geology" sheet of the Rome folio (Hayes, 1902). Brown ore is typically more abundant along lines of bauxite deposits than at either side of such lines. Although abundant brown iron ore does not necessarily indicate proximity to bauxite deposits, a great many bauxite mines and prospects have pockets of brown ore within 100 or 200 feet.

\section{ORIGIN}

The origin of the bauxite deposits involves many factors that go far beyond the scope of this investigation, and the reader is referred to the work of Spencer (1893), Hayes (1895), Watson (1904), Adams (1923), and Bridge (1950) for detailed accounts of the various theories that have been proposed. Only a brief recapitulation is attempted here.

Spencer (1893, p. 225-226) suggested that certain layers within the dolomite itself might contain more highly aluminous impurities than the average and that, on solution and removal of carbonate, the aluminous constituents would be concentrated to form the bauxite deposits.

Hayes (1895), followed by Watson (1904), believed that an artesian circulation oxidized pyrite in the Conasauga Formation and that the resulting sulfuric acid leached alumina from the shale and redeposited it after carrying it to the surface through cracks and fissures in the overlying dolomite of the Knox Group. The depth of the required circulation, the scarcity of pyrite in the shale of the Conasauga Formation, and the age of the deposits oppose this theory. The similar age of the deposits in the area of Paleozoic rocks and on the Coastal Plain 
must be regarded as pure coincidence if those of Northwest Georgia are due to an artesian circulation and unrelated to climate.

Adams (1923) suggested that the deposits were formed by weathering of kaolin in sinkholes. Bridge (1950) elaborated this theory in proposing that the kaolin was derived from the Blue Ridge and Piedmont provinces to the north and east in much the same manner and perhaps at the same time as was the sedimentary kaolin of the Coastal Plain and that the trapping of this kaolin in sinkholes has led to its preservation in isolated patches. As we have previously stated, the altitudes of some deposits make it necessary to modify Bridge's theory, either in terms of the altitude of the surface of deposition or in terms of the ultimate source of the kaolin.

\section{OUTLOOK FOR FURTHER DISCOVERIES}

With few exceptions the known deposits of bauxite in Northwest Georgia have been discovered through surface showings of ore. In the heyday of bauxite mining, many producers offered rewards to encourage prospectors, and nearly all surface indications in the region must have already been found. The larger the deposit, furthermore, the more likely it is to have cropped out and to have been discovered. Many truly large deposits, containing in the neighborhood of 100,000 tons or more, probably do not remain hidden in the region, except possibly in headwater areas of high altitude and low relief away from the plateau rim. Though the possibilities for further important bauxite discoveries must accordingly be regarded as remote, bodies containing appreciable quantities of ore probably remain to be found through systematic exploration. Quantities ranging in order of magnitude from 2,000 to 20,000 tons might well be expected. The problem of prospecting for such deposits involves various factors related primarily to regional and local stratigraphy, geologic structure, and geomorphology.

\section{RECOMMENDATIONS FOR EXPLORATION}

In any search for additional deposits of bauxite in the Northwest Georgia district, sites at which formations other than those of the Knox Group crop out may well be disregarded; these areas are, empirically, unfavorable for its occurrence. Restriction of any such search primarily to areas underlain by the Knox Group is accordingly recommended. The results of our study do not, however, suggest association of the bauxite deposits with any particular stratigraphic interval or intervals within the group.

As a measure of the chances of discovery, the number of deposits per unit area (concentration of deposits) at a given altitude is more 
significant than the total number of deposits at that altitude. On the basis of number per unit area, higher altitudes are generally more favorable for prospecting than lower altitudes within the area of known deposits outlined in figure 1. The large number of deposits at altitudes near 885 feet is believed to be due in part to the large proportion of the land surface that is near this altitude and does not mean that places at higher altitudes are less favorable; they may be more favorable. Places less than 800 feet above sea level, however, are definitely unfavorable.

In selecting areas for exploration within the Northwest Georgia bauxite district, alinement of deposits already found is the most useful single criterion, notwithstanding the danger of exaggerating its significance. Favorable areas for prospecting lie between known deposits that occur along a line, as well as beyond such deposits in either direction along the line. The distribution of test holes near many mines shows clearly that operators have been aware of the usefulness of this alinement principle. If, however, the principle were to be applied exclusively and rigidly as a prospecting technique, some ore bodies that would otherwise be found would probably remain undiscovered, and an unnecessarily large number of lines with no real validity would doubtless be drawn. Individuals who use alinement of deposits as prospecting guides should attach more significance to alinements that satisfy several of the following theoretically favorable conditions than to alinements that only satisfy one or two:

1. Occurrence along the trace of a known fault (Hayes, 1895, p. 597).

2. Occurrence of two or three deposits fairly close to one another (no more than a mile or so apart) on a line that closely parallels the trace of a known fault.

3. Occurrence of three or more deposits close together along a line even though the line may not be obviously related to known faults.

4. Marked elongation of a bauxite deposit. (Its location and the direction of its longitudinal axis define a line along which other deposits are likely to occur; this is especially true of any two or more such deposits that extend along the same line-(for example, the Red Warrior and Fat John deposits in the Bobo district.)

5. Coincidence of a line of deposits with a line of topographic features of types that commonly mark the traces of faults. (The most conspicuous examples of lines of this description in Northwest Georgia coincide in part with well-defined ravines; where such lines intersect ridges, they commonly do so at low points along their crests.) 
6. Occurrence of brown iron ore or kaolinitic clay along a line that is believed to coincide with the trace of a fault. (This criterion is almost as dependable as bauxite float (Hayes, 1895, p. 597).) The limits of the part of the Northwest Georgia bauxite district described in this chapter are fairly well defined and can be drawn as smooth lines without too much generalization (fig. 1). The district. has long been recognized as continuing westward to the Rock Run area. in Alabama. In part the limits of the district coincide with the limits of the outcrop belt of the Knox Group, as they do east and south of Rome and at the east termination of the district. Where the district limits are within the outcrop belt of the Knox Group, there is, presumably, some other explanation for their location. For example, the southeast limit of the district may mark the border of a broad ancient. valley bottom on which kaolin was transported and deposited. Until we have a more complete knowledge of ancient physiography and drainage in the region, however, the boundaries of the district must remain empirical, and one can only say that at present the chances of new discovery beyond these limits seem to be much less than inside them.

Inasmuch as the deposits that have already been found in Northwest Georgia are believed to include all, or nearly all, occurrences of bauxite where this material once cropped out or formed float, any ore bodies as yet undiscovered probably occur where such materials are concealed by bauxite-free surficial debris that has accumulated above them. Future search for ore bodies, therefore, may well be concentrated in areas occupied by such debris. Areas deserving special attention would presumably be those occupied by waterborne debris in the aggrading bottoms of broad ravines and valleys and those in which accumulations of bauxite-free debris have slid downward from the upper and middle parts of slopes.

An additional type of site might be profitably explored. Major drainage divides, or headwater areas well away from plateau rims, also provide conditions favorable for preservation and concealment of bauxite deposits, as we discussed previously, although whether or not such areas contain major deposits remains to be demonstrated. The following paragraphs suggest places at which the possibility of such concealed large deposits can be tested.

In the Hermitage area, a major divide crosses the dolomite plateau near the north line of sec. 3 , dist. 16. The topography of this general headwater area is gently rolling, most of the hillocks rising less than 40 feet above the adjoining swales. As elsewhere, deposits are more likely to remain concealed between, rather than on, the hillocks of this rolling upland, and places favorable for prospecting can be selected on this basis. A number of such sites are indicated on plate 1 to the 
north, west, and southwest of Snow Spring. The more easterly areas are fairly close to the plateau rim extending south from Adairsville, but there the subdued topography characteristic of the divide west of Snow Spring extends eastward almost to the rim.

Another comparable headwater area of subdued relief lies southeast of the rim of Cassville Mountain, 4 to 5 miles southeast of Adairsville and northeast of U.S. Highway No. 41. This area is beyond the limits of the area of known deposits outlined in figure. 1.

Specific areas that are considered to be most favorable for exploration for concealed deposits of bauxite are shown on some of the geologic maps (pls. 1-3). These areas have been chosen almost entirely on the basis of alinement with known deposits and the chance of concealment. Conditions of topography and stratigraphy are generally favorable.

\section{DESCRIPTION OF DEPOSITS}

The writers examined about 180 bauxite deposits in the course of their investigations. The location of each is shown on the maps (pls. $1-3$; figs. 2,3 ). The deposits described in the following paragraphs include the major mines and also some of the minor occurrences that illustrate either common or exceptional characteristics of the deposits. Most of the deposits described are mentioned in the text. A preliminary report (White and Denson, 1952, p. 11-26) contains descriptions of all the deposits and gives the altitude of most.

At most deposits little can be seen at present (1964). Test holes and pit walls have slumped ; and water, leaves, and surficial debris conceal almost everything that was exposed in the original openings. The nature of the materials obtained from old openings is generally best determined by examining the dumps and piles adjacent to holes and pits.

Although the descriptions of deposits are based primarily on our own observations, they are supplemented in places by data from other sources. The principal source of supplementary information is the report by Watson (1904), who visited the district when many of the mines were operating. His data are summarized in many of the descriptions that follow. Local residents and bauxite miners have also been regarded as reliable sources, especially for such information as the original depth of pits now filled with water. Even a few observations of geologic significance, such as the character of a pipelike mass of lignite in the Booger Hollow mine, were reported by so many individuals that they may be regarded as accurate.

Most of the chemical analyses are based on figures published by Watson. A few others were obtained from the Georgia Geological Survey 
at Atlanta. Analyses of samples collected by the writers were made by chemists of the U.S. Geological Survey in Washington, D.C.

The deposits are described by areas, in numerical order of section, district, and land lot to facilitate cross-reference with the maps (pls. $1-3$; figs. 2, 3). Lot lines and the larger mines are readily visible on the aerial photographs used in this study, and the locations of deposits with respect to land lots are generally accurate on the maps and in the text. In a few heavily wooded areas, particularly the one southeast of Adairsville, the locations of the deposits in relation to roads, drainage, and geologic boundaries are accurate, but there may be errors in their relation to land lot lines as shown on the map.

\section{HERMTTAGE AREA}

(P1.1)

\section{BECTION 3, DIBTRICT 5}

Lot \%.--The Curtis (also known as Cherokee, Akin, or Merrimac) mine (alt 900-930 ft) is mostly in the NE1/4 lot 7, along ravines both east and west of a saddle. There are five large pits and many test holes in a line 1,500 feet long. The three easternmost pits form a continuous opening, and the other two are separated by areas underlain by kaolinitic clay or residual clay. The largest pit, near the west end of the line of openings, was probably about 100 by 350 feet in original dimensions and as much as 50 feet deep. Most of the walls of this pit now expose residual clay. The walls of the eastern pits contain a large amount of bauxitic clay with scattered pebbles and boulders of pisolitic bauxite; the bauxite is in contact with kaolinitic clay on the north at all places, but the south boundary is mostly concealed by slump. The arrangement of pits and the exposures in them suggest that the deposit is a vertical tabular body of kaolinitic clay with walls of cherty residual clay and, locally, a core of bauxite; the body is wide in some places and narrow in others. Bauxite seems to form the core only in the wide places, now marked by pits. At the east end of the largest pit, the deposit is merely a narrow vertical veinlike mass of kaolinitic clay between walls of residual clay.

A sample of bauxite from the drying bin, analyzed in 1929 by the Geological Survey of Georgia, contained 49.80 percent $\mathrm{Al}_{2} \mathrm{O}_{3}, 1.40$ percent $\mathrm{Fe}_{2} \mathrm{O}_{3}, 2.25$ percent $\mathrm{TiO}_{2}$, and 24.65 percent $\mathrm{SiO}_{2}$, with 21.90 percent loss on ignition.

\section{GECTION 3, DISTRICT 16}

Lots 10 and 21.-The Terry-Shaw mine (alt 1,075 ft) is on both sides of the north border of the NE1/4NW $1 / 4$ lot 21 , on the crest of a high ridge. The pit covers an area about 200 feet square and averages 
20 feet in depth; its walls and floor contain pink and red clay with scattered pebbles and boulders of hard pink and white pisolitic bauxite. The clay was washed from the pisolitic material to make a commercial product. Analyses of 13 samples cited by Watson (1904, p. 78) average 56.2 percent $\mathrm{Al}_{2} \mathrm{O}_{3}, 3.07$ percent $\mathrm{Fe}_{2} \mathrm{O}_{3}, 2.98$ percent $\mathrm{TiO}_{2}$, and 7.82 percent $\mathrm{SiO}_{2}$. A large horse of cherty clay occurs in the center of the pit, but the bottom of the deposit does not seem to have been reached.

Lot 37 -A prospect in the NE $1 / 4 \mathrm{SW}^{1 / 4}$ lot 37 lies in a saddle, just east of the crest of a ridge. This deposit, at an altitude of 1,110 feet, is the highest in the region. A pit, 30 feet long, 15 feet wide, and probably 20 feet deep before slumping, exposes pebbles and boulders of white pisolitic bauxite in a matrix of red clay. In test holes to the east and west residual clay was found.

Lot 54.-The Mary mine (alt 1,020 ft), in the SW1/4 SE1/4 lot 54, is on the steeply sloping east end of a ridge. A pit, 100 feet long, 50 feet wide, and about 15 feet deep, exposes boulders of bauxite in pebbly bauxitic clay, firm white pebbly bauxite, and some reddish pisolitic bauxite. The walls also contain abundant kaolinitic clay and some cherty residual clay. The ore body is very irregular, as indicated by the pit and adjacent test holes; it may extend south of the explored area. A layering of the clay and bauxite in the walls is locally apparent, and the layers dip gently southeast, roughly parallel with the slope of the surface. The deposit may be a thin blanket. Analyses of 12 samples of the ore mined (Watson, 1904, p. 81) averaged 58.98 percent $\mathrm{Al}_{2} \mathrm{O}_{3}, 2.40$ percent $\mathrm{Fe}_{2} \mathrm{O}_{3}, 3.48$ percent $\mathrm{TiO}_{2}$, and 4.13 percent $\mathrm{SiO}_{2}$.

Lot 60.-The nature, location, topographic position, and altitude of the openings in lot 60 are shown in figure 3 . The Hardee mine (alt at north end, $910 \mathrm{ft}$ ) consists of two contiguous funnel-shaped pits about 30 feet deep. The walls are formed mostly of pink and white kaolinitic clay and minor amounts of cherty clay. The bauxite on the dump is white, in part pebbly and in part pisolitic.

The North Hardee mine (alt $900 \mathrm{ft}$ ) is a pit, possibly 30 feet deep originally. The slumped walls contain a little kaolinitic clay, but mostly cherty residual clay. Bauxite scattered around the pit is light-colored to red, and either pisolitic or pebbly.

Lot 11\%.-The Julia mine (alt $850 \mathrm{ft}$ ), largest in the district, is in the NW1/4 of lot 117, on the gentle slope to the north of a broad flat bottom. This mine, whose total production prior to 1942 is estimated to have been about 70,000 tons, consists of two circular pits about 300 feet apart, each about 220 feet across. The northwestern, or No. 1, pit was mined to a depth of 90 feet, and the bauxite is known to extend 
at least 40 feet deeper. The bauxite was mostly coarse pebble ore with some boulders. No. 2 pit was mined to a depth of 60 feet, but 15 to 20 feet of slumped material covered the bottom when the pit was pumped out in 1942. Test shafts dug in the northern part of the bottom at this time indicated reserves of more than 20,000 tons. The ore in these shafts was soft mottled pink and white bauxite with abundant imperfectly formed pisolites and with many pebbles and boulders of hard pink and white pisolitic bauxite. The average of 26 analyses of bauxite from the Julia mine cited by Watson (1904, p. 86), probably from both pits, was 58.2 percent $\mathrm{Al}_{2} \mathrm{O}_{3}, 1.08$ percent $\mathrm{Fe}_{2} \mathrm{O}_{3}, 4.09$ percent $\mathrm{TiO}_{2}$, and 6.41 percent $\mathrm{SiO}_{2}$. Two samples from No. 2 pit analyzed more recently by the Georgia Geological Survey contained an average of about 55 percent $\mathrm{Al}_{2} \mathrm{O}_{3}$ when recalculated to 30 percent moisture.

Between and slightly south of the two main pits is a small pit, now largely filled.

A small pit (alt $860 \mathrm{ft}$ ) in the $\mathrm{SW} 1 / 4 \mathrm{NE} 1 / 4$ lot 117,900 feet southeast of the Julia mine, was more or less filled by alluvial material at the time of the writers' visit. Material on the dump was white pebble and pisolitic bauxite. This deposit, the Little Julia, was later reopened by the American Cyanamid Co. and had been mined out by the summer of 1953 (E. F. Overstreet, oral commun.). Scattered test holes between the Little Julia and Julia mines examined in 1942 seemed too shallow to have penetrated the overburden.

Lot 128.-The Conneseena (also known as the Felder or Knowles) mine (alt 780-800 ft) is a long line of pits and test holes in the middle of the south half of lot 128, along the bottom of a ravine. These openings occupy an area about 500 feet long, measured nearly east-west, and about 50 feet wide. None of the pits seems to be more than 20 feet deep, and the largest is only 50 feet across. Most of the bauxite consists of light-colored pisolitic boulders and pebbles in a matrix of reddish clay and light-colored bauxitic clay. In places the bauxite is coarse, white, and vesicular or pebbly. The westernmost openings contain much pink nonpisolitic clay. The few observed contacts between different kinds of bauxite and clay appear to strike parallel to the elongation of the deposit and to dip steeply, a situation suggesting that the deposit as a whole may be a steeply dipping veinlike body similar to that of the Curtis mine (dist. 5, lot 7), described above. The deposit probably extends farther into the SE $1 / 4$ lot 128 than is suggested by the mine symbols on plate 1 , on the basis of holes drilled in the late 1950's (S. H. Patterson, oral commun.). Four samples of bauxite from the Conneseena mine, analyzed by the Georgia Geological Survey, contained an average of 54.35 percent 
$\mathrm{Al}_{2} \mathrm{O}_{3}, 4.76$ percent $\mathrm{Fe}_{2} \mathrm{O}_{3}, 2.76$ percent $\mathrm{TiO}_{2}$ and 10.63 percent $\mathrm{SiO}_{2}$, with 26.05 percent loss on ignition.

Well-rounded pebbles of coarse-grained quartzite in the pink and white residual clay adjacent to the bauxite in the westernmost pit indicate that drainage from the Piedmont province once crossed this area. This inference may bear on the origin of the kaolinitic clays from which the bauxite is presumed to have formed (Bridge, 1950, p. 195).

Lot 176.-The Hawkins (also known as Shaw) mine (alt $690 \mathrm{ft}$ ) lies in the $\mathrm{NW}_{1} 1 / 4 \mathrm{SE} 1 / 4$ lot 176 , on the east side of the broad valley bottom of Barnsley Creek. It is a large oval pit, about 225 feet long, 150 feet wide, and said to be 30 to 40 feet deep; the opening is now filled almost to its rim with water. The walls above the water are only kaolinitic clay and residual clay, and there is not enough bauxite lying around on the surface to indicate the character of the ore.

\section{SECTION 3, DISTRICT 23}

Lot 61.-Lot 61 contains most of the Holland group of pits, whose size, location, topographic position, and altitude are shown in figure 3. The pits are mostly full of water and badly slumped.

The walls of the Holland mine are mostly in residual clay, with a little kaolinitic clay in places. Watson $(1904$, p. 63) described the ore as hard light-colored bauxite with dark crumbly ferruginous pisolites; he stated that a shipment of 106 carloads contained an average of 52.93 percent $\mathrm{Al}_{2} \mathrm{O}_{3}, 9.23$ percent $\mathrm{Fe}_{2} \mathrm{O}_{3}, 3.49$ percent $\mathrm{TiO}_{2}$, and 4.55 percent $\mathrm{SiO}_{2}$, with 29.80 percent loss on ignition. The first shipments of bauxite in the United States came from this mine.

Only cherty red clay can be seen in the slumped walls of the shallow Holland Hill mine. Fragments of fine white pisolitic bauxite are strewn around the opening. This mine must be the more western of two pits described by Watson $(1904$, p. 63) as the Church bank.

The walls of the Holland Spring mine are in cherty residual clay and a little kaolinitic clay. The original opening was about 75 feet deep (Veatch, 1909, p. 266). Watson (1904, p. 61) described the ore from this mine as "a soft bauxitic clay through which are scattered small varicolored concretions." Some of the ore was hard buff colored, and oolitic. The ore body was cut by veins and horses of clay several feet wide, and small lenses of hard dense white clay were abundant in the bauxitic clay.

The Discovery pit shows red clay and a little coarse pisolitic bauxite in its slumped walls. The first material identified as bauxite in the United States was taken from this pit, according to Mr. W. T. Watters, local agent of the Republic Bauxite Co. 
The Holland House mine was probably about 40 feet deep when operated. The walls now are mostly in kaolinitic clay and cherty clay, but a few patches of soft white bauxite and hard pisolitic bauxite remain. Some hard pisolitic boulders are present on the dump. A hundred tons of ore contained an average of 51.65 percent $\mathrm{Al}_{2} \mathrm{O}_{3}, 1.29$ percent $\mathrm{Fe}_{2} \mathrm{O}_{3}, 3.49$ percent $\mathrm{TiO}_{2}$, and 10.62 percent $\mathrm{SiO}_{2}$, with 32.45 percent loss on ignition (Watson, 1904, p. 62).

The Church mine, largest of the Holland pits, was at least 75 feet deep when operated (Veatch, 1909, p. 266). Only cherty clay is now exposed in the walls. Watson $(1904$, p. 63) described the ore as soft pebbly bauxite with subordinate hard pisolitic bauxite. Samples representing 300 tons contained an average of 55.30 percent $\mathrm{Al}_{2} \mathrm{O}_{3}$, 1.02 percent $\mathrm{Fe}_{2} \mathrm{O}_{3}, 4.04$ percent $\mathrm{TiO}_{2}$, and 8.04 percent $\mathrm{SiO}_{2}$ with 31.60 percent loss on ignition (Watson, 1904, p. 65).

The walls of the Southwest Lenning mine are mostly in white kaolinitic clay with a little pisolitic and pebbly white bauxite. Test. holes on the south side are in residual clay.

The Northeast Lenning mine exposes only cherty clay and a little kaolinitic clay in its walls. The ore was white bauxite with brown pisolites. Test holes to the east and west show no bauxite.

Lot 62.-The New Holland mine (fig. 3) contained hard white pebble and oolitic bauxite. The area between the New Holland and Holland Spring mines is now (1965) occupied by a large pit connecting the two openings.

Lot 138.-The Maddox mine (alt $805 \mathrm{ft}$ ) lies in a broad flat valley bottom, in the $\mathrm{NW} 1 / 4 \mathrm{NE} 1 / 4$ lot 138 . Two contiguous circular pits, which cover a total area about 275 feet long and 130 feet wide, are filled to their rims with water. According to Watson (1904, p. 71), the ore consisted of hard and soft pisolitic bauxite, generally white, with some highly ferruginous red masses. He gave three analyses, which averaged 62.35 percent $\mathrm{Al}_{2} \mathrm{O}_{3}, 2.51$ percent $\mathrm{Fe}_{2} \mathrm{O}_{3}$, and 4.32 percent $\mathrm{SiO}_{2}$. Lot 14\%.-The Watters (Perry) mine (alt $935 \mathrm{ft}$ ) is on the gentle south slope of a hill near its top, in the NW1/4 NW1/4 lot 147 , crossing slightly into lot 148. It consists of two large contiguous pits, separated by a knife-edge chert ridge. The mine produced about 60,000 tons of bauxite. The larger northwest pit is 350 feet long, 200 feet wide, and at least 50 feet deep. It exposes only cherty clay in its walls, except for a little bauxitic clay at the southwest end. According to Watson (1904, p. 73) the ore was soft light-colored pisolitic bauxite with hard white pisolitic pebbles and boulders. He cited 15 samples $(1904$, p. 73 ) which contained an average of 56.6 percent $\mathrm{Al}_{2} \mathrm{O}_{3}, 1.1$ percent $\mathrm{Fe}_{2} \mathrm{O}_{3}$, and 7.2 percent $\mathrm{SiO}_{2}$. The southeast pit is 250 feet long, 175 feet wide, and 30 feet deep. Its walls contain cherty 
clay and abundant bauxitic clay with white pebbles. Watson (1904, p. 72) described the ore as soft ferruginous pebbly bauxite with some boulders and cited analyses of 11 samples which averaged 49.7 percent $\mathrm{Al}_{2} \mathrm{O}_{3}, 1.77$ percent $\mathrm{Fe}_{2} \mathrm{O}_{3}$, and 10.6 percent $\mathrm{SiO}_{2}$.

\section{BOBO AREA}

(Pl. 2)

\section{SECTION 8, DISTRICT 22}

Lot 23.-Two large mines have been opened on Ware Mountain in lot 23. The North Ware Mountain mine (alt $950 \mathrm{ft}$ ) is in the SE1/4 NW $1 / 4$ lot 23 , on the east side of the broad crest of the mountain. In the northeast corner of the pit, which is about 150 feet long, 100 feet. wide, and at least 30 feet deep, brown and white bauxitic clay containing pebbles and boulders of hard white pisolitic bauxite is exposed. The other pit walls are composed of kaolinitic clay and cherty residual clay. The kaolinitic clay is every where on the pit side of the residual clay, and the contacts between kaolinitic clay and residual clay dip inward under the ore.

The South Ware Mountain mine (alt $935 \mathrm{ft}$ ), in the NE1/4 SW $1 / 4$ lot 23 , is at a fork on the south side of a broad ravine cutting the east slope of the mountain. The pit is 130 feet long and 60 feet wide. In the west wall there is some soft white bauxite, or bauxitic clay, with pebbles and boulders of hard white pisolitic bauxite. The other walls expose kaolinitic clay and a little cherty clay.

Lot 53.-The Broadaway (Bigelow) mine (alt 960-980 ft) consists of two contiguous pits near the middle of the SW1/4 lot 53, on the crest and upper west side of a ridge. The eastern pit is funnel shaped, about 100 feet across and 30 feet deep. The south and west walls expose white nonpisolitic bauxitic clay, locally containing pebbles of white bauxite. The other walls are in residual clay near the top and kaolinitic clay near the bottom. The western pit is 175 feet long, 75 feet wide, and 15 feet deep. The north wall is of soft white bauxitic clay, some containing pebbles and small boulders of bauxite. Hard brown vesicular bauxite locally overlies the bauxitic clay. Test holes in the pit floor penetrated bauxite.

\section{SECTION 4, DISTRICT 3}

Lot 606.-The Red Warrior mine (alt $865 \mathrm{ft}$ ) crosses the east line of the NE1/4 lot 606 , near the top of the west slope of a high ridge. The pit is 100 feet long, 20 to 30 feet wide, and about 20 feet deep in the deepest part. The walls show mostly massive medium-hard coarsely pisolitic mottled red and yellow bauxite with scattered red boulders. The deposit is far from worked out, but most of the mate- 
rial mined from the pit has evidently gone on the dump. Watson $(1904$, p. 95$)$ gave three analyses, which averaged 55.06 percent $\mathrm{Al}_{2} \mathrm{O}_{3}$, 7.12 percent $\mathrm{Fe}_{2} \mathrm{O}_{3}, 4.45$ percent $\mathrm{TiO}_{2}, 1.83$ percent $\mathrm{SiO}_{2}$, and 32.33 percent $\mathrm{H}_{2} \mathrm{O}$.

Lot $60 \%$.- The Fat John mine (alt $905 \mathrm{ft}$ ) lies up the slope 100 feet east of the Red Warrior mine in the $\mathrm{NW}^{1} / 4$ lot 607 . The pit is 200 feet long and 75 feet wide and is 35 feet deep at the east end. The Fat John and Red Warrior mines are elongate east-west and lie on the same east-west line. 'The northwest part of the Fat John pit shows a little pebbly bauxite and pink nonpisolitic clay, but the other walls show only kaolinitic clay and residual clay. According to Watson (1904, p. 94), the ore was dense buff pisolitic bauxite, and the pisolites had powdery red nuclei. An analyzed sample contained 61.31 percent $\mathrm{Al}_{2} \mathrm{O}_{3}, 1.04$ percent $\mathrm{Fe}_{2} \mathrm{O}_{3}, 4.58$ percent $\mathrm{TiO}_{2}, 1.40$ percent $\mathrm{SiO}_{2}$, and 31.70 percent $\mathrm{H}_{2} \mathrm{O}$.

Lot 691. - The Hyram Bobo prospect (alt $835 \mathrm{ft}$ ) in the SE1/4 SW1/4 lot 691 is just north of the bottom of Booger Hollow. More than 50 test holes, including 30 put down under the direction of the Georgia Geological Survey, outline an irregular area of about 20,000 square feet underlain by bauxitic clay; within this area two patches, 150 feet apart and probably totaling 4,000 square feet, are underlain by soft to hard white bauxite with pink and white pisolites. A pit was being opened in each of these two bauxite patches in 1942. A 5-foot channel sample collected by the writers from the more southerly pit contained 51.38 percent $\mathrm{Al}_{2} \mathrm{O}_{3}, 1.58$ percent $\mathrm{Fe}_{2} \mathrm{O}_{3}, 3.66$ percent $\mathrm{TiO}_{2}$, and 13.20 percent $\mathrm{SiO}_{2}$; and a 4 -foot sample from the other pit contained 47.22 percent $\mathrm{Al}_{2} \mathrm{O}_{3}, 4.52$ percent $\mathrm{Fe}_{2} \mathrm{O}_{3}, 4.00$ percent $\mathrm{TiO}_{2}$, and 16.53 percent $\mathrm{SiO}_{2}$. The area enclosing the bauxite patches contains scattered pebbles of white bauxite in pink and white bauxitic clay. The pebbles probably make up 5 to 10 percent of the volume of this material and contain an average of 55.34 percent $\mathrm{Al}_{2} \mathrm{O}_{3}, 2.28$ percent $\mathrm{Fe}_{2} \mathrm{O}_{3}, 3.67$ percent $\mathrm{TiO}_{2}$ and 8.46 percent $\mathrm{SiO}_{2}$. The clay and pebbles combined contain about 43 percent $\mathrm{Al}_{2} \mathrm{O}_{3}$ and 30 percent $\mathrm{SiO}_{2}$. Many pits surrounding the area of bauxitic clay penetrated only kaolinitic clay and cherty clay. This deposit represents a northerly extension of the main Booger-Hollow deposit in lot 750 .

Lot 750.-The Booger Hollow mine (alt $830 \mathrm{ft}$ ) is in the bottom of Booger Hollow in the $\mathrm{NE}_{1 / 4} \mathrm{NW} 1 / 4$ lot 750 . The main pit is 250 feet long, 200 feet wide, and was more than 45 feet deep; a smaller pit lies 150 feet to the northwest. Total production from the two pits was about 60,000 long tons. Above the water line in 1942, the walls of the main pit exposed a little kaolinitic clay on the south side and gravel and residual clay elsewhere. The walls of the bauxite mass were steep, 
and near the center of the body a pipelike mass of lignite as much as 25 feet across extended downward at least to the bottom of the pit. Fragments of the lignite collected from the dump by R. W. Brown were found to contain plant fossils of Eocene or older age (Bridge, 1950, p. 194; Cloud and Brown, 1944, p. 1466). The ore from the main pit was hard light-colored pebbly and pisolitic bauxite. Ore from the smaller pit was hard and soft pink to white pisolitic bauxite.

Lot 910.-The Henry mine (alt $855 \mathrm{ft}$ ) is just south of the center of lot 910 on the south side and bottom of a small deep ravine. An area 200 feet long and 120 feet wide has been stripped to a depth of a few feet, and about 4,000 tons of bauxite has been removed. Adjacent test holes indicate that bauxite extends beyond the stripped area. Hard dark red pisolitic bauxite with crumbly red pisolites is interlayered with pink to cream-colored bauxitic clay with a few ferruginous pisolites. The layers are a few inches to 8 feet in thickness and dip in the same direction but more steeply than the surface slope. Watson (1904, p. 99) mentioned a 40-foot shaft at this deposit that penetrated bauxite for its entire depth, so the deposit is far from exhausted. He gave five analyses, which averaged 58.21 percent $\mathrm{Al}_{2} \mathrm{O}_{3}, 8.02$ percent $\mathrm{Fe}_{2} \mathrm{O}_{3}$, and 4.50 percent $\mathrm{SiO}_{2}$.

CAVE SPRING AREA

(Pl. 3)

SECTION 4, DISTRICT 2

Lot 214.-The Hampton (Hebble) mine (alt $940 \mathrm{ft}$ ) is on the lower southeast slope of a high hill in the SW1/4 SW1/4 lot 214. The main pit is 150 feet wide, 250 feet long, and at least 60 feet deep. The walls contain kaolinitic clay and cherty clay, for the most part, but there is a little soft ferruginous pisolitic bauxite at the west end. The ore consisted of boulders and masses of hard white pisolitic bauxite with minor soft bauxite between. The pisolites range from reddish and crumbly to white and hard. A small pit adjoining the main pit on the northwest side has completely slumped walls.

SCATTERED DEPOSITS OF SOUTHEASTERN FLOYD AND SOUTHWESTERN BARTOW COUNTIES

(Fig. 2)

SECTION 3, DISTRICT 17

Lot 5\%1. - The Fountain mine (alt $775 \mathrm{ft}$ ), in the $\mathrm{NW} 1 / 4$ lot 571 , is in a broad shallow swale. When visited in 1952, the deposit had been mined out (E. F. Overstreet, oral commun.). In 1943, it had been explored by several test pits and about 40 auger holes. The owner's 
description of the results of this exploration suggested that an area 250 feet long and 175 feet wide was underlain by bauxite to a maximum depth of 40 feet. Several of the test holes revealed massive pinkishwhite vesicular bauxite with many imperfect crumbly dark-red pisolites. Most of the bauxite piled beside the pit in 1952 was dark red and pisolitic.

\section{SECTION 3, DISTRICT 22}

Lot 129.-The Bradshaw (Bonsack) mine (alt $790 \mathrm{ft}$ ) is near the NE. cor. lot 129, in the bottom of a broad valley. During 1941-42, a total of 12 carloads of ore, containing considerable clay, was shipped for use in the manufacture of refractory brick. The pit was 175 feet long and 60 feet wide, elongate northeast, and 30 feet deep when visited in 1942. Most of the walls contained boulders and pebbles of dark-red and grayish-white pisolitic bauxite in a matrix of red and white bauxitic clay. Both ends of the pit cut sandy residual clay. Test holes put down under the direction of the Geological Survey of Georgia indicate that the ore body is about 175 feet long and 100 feet wide, with residual clay beyond on all sides. Test holes in the bottom of the pit at both ends indicate that ore continues at least 20 feet below the bottom. Watson (1904, p. 110) gave the following analyses (in percent) of ore from this mine:

\begin{tabular}{|c|c|c|c|c|c|}
\hline & $\mathrm{Al}_{2} \mathrm{O}_{3}$ & $\mathrm{Fe}_{2} \mathrm{O}_{3}$ & $\mathrm{TiO}_{2}$ & $\mathrm{SiO}_{2}$ & $\mathrm{H}_{2} \mathrm{O}$ \\
\hline $\begin{array}{l}\text { Red ore } \\
\text { Light ore }\end{array}$ & $\begin{array}{l}52.40 \\
56.96\end{array}$ & $\begin{array}{r}12.60 \\
1.69\end{array}$ & $\begin{array}{l}\text { 3. } 70 \\
4.05\end{array}$ & $\begin{array}{l}3.95 \\
6.03\end{array}$ & $\begin{array}{l}27.35 \\
31.40\end{array}$ \\
\hline
\end{tabular}

This deposit is of interest as an exception to the general rule that bauxite occurs only in areas underlain by the Knox Group. The clays that surround this bauxite body were almost certainly derived from carbonate rocks of the upper part of the Conasauga Formation rather than the dolomite of the Knox Group. Cherty residual clays of the Knox are found on the ridge half a mile farther east.

\section{SECTION 3, DISTRICT 23}

Lot 332.-The Freeman prospect is in the SE $1 / 4 \mathrm{SW}^{1 / 4}$ lot 332 , on the lower west side of a deep narrow ravine. This deposit, at an altitude of 645 feet, is the lowest in the region. Several shallow pits expose a body of hard red pisolitic bauxite. Watson (1904, p. 113) gave the following analysis: 56.00 percent $\mathrm{Al}_{2} \mathrm{O}_{3}, 9.64$ percent $\mathrm{Fe}_{2} \mathrm{O}_{3}$, and 6.31 percent $\mathrm{SiO}_{2}$. Surrounding test holes in chert and sandy clay suggest that the deposit may be 50 feet wide and 60 to 100 feet long. 


\section{BAUXITE DEPOSITS, SUMMERVILLE AREA, GEORGIA}

By John C. Dunlap and Elizabeth F. Overstreet

\section{GENERAL FEATURES}

The bauxite deposits of the Summerville area (fig. 5), in Chattooga and Walker Counties, Northwest Georgia, were investigated early in the autumn of 1942 as part of the Geological Survey's wartime study of bauxite deposits in the United States. Adjacent parts of Chattooga, Catoosa, Walker, and Dade Counties were also investigated briefly. Mining and exploration for bauxite in the Summerville area were most active in the last few years of the nineteenth century and the first few years of the twentieth.

The Summerville area lies within the Valley and Ridge province of the Appalachian Mountains. Its drainage is mainly southwestward, in the direction of the prevailing strike of the underlying rocks of Paleozoic age. All the known bauxite deposits are within the drainage basin of the Chattooga River. They occur on slopes of hills or ridges at altitudes ranging from 725 to 900 feet above sea level.

The bauxite is generally pisolitic; some of it is red and some is white. All the deposits occur as pods, or bodies roughly elliptical in plan, in areas underlain by sedimentary rocks of the Knox Group of Cambrian and Ordovician age, and all are associated with residual clay derived from dolomitic strata belonging to that group. In some deposits the bauxite is present only as dornicks of high-grade ore in bauxitic clay; this clay grades outward into smooth red-and-white-mottled kaolinitic clay.

The geologic map (fig. 5), generalized from that published by Butts and Gildersleeve (1948), shows the extent of the belts in which the Knox Group crops out in the Summerville and adjacent areas and shows the locations of five known bauxite deposits in relation to major geologic features.

Three of the deposits are at the west edge of the town of Summerville. A fourth, near Trion, is about 7 miles to the northeast along the same general belt of outcropping rocks of the Knox Group. The fifth, which is in Walker County, about 5 miles northwest of Trion, is in another such belt. Bauxite is not known to occur elsewhere in that part of Northwest Georgia shown in figure 5; the Chattanooga district, in Tennessee, is just across the State line, about midway along the north boundary of the map, and might be expected to extend southward along the fault between the Knox and older rocks. The once important deposits of the Hermitage, Bobo, and Cave Springs areas are south and southeast of the Summerville area but do not extend in this direction. 


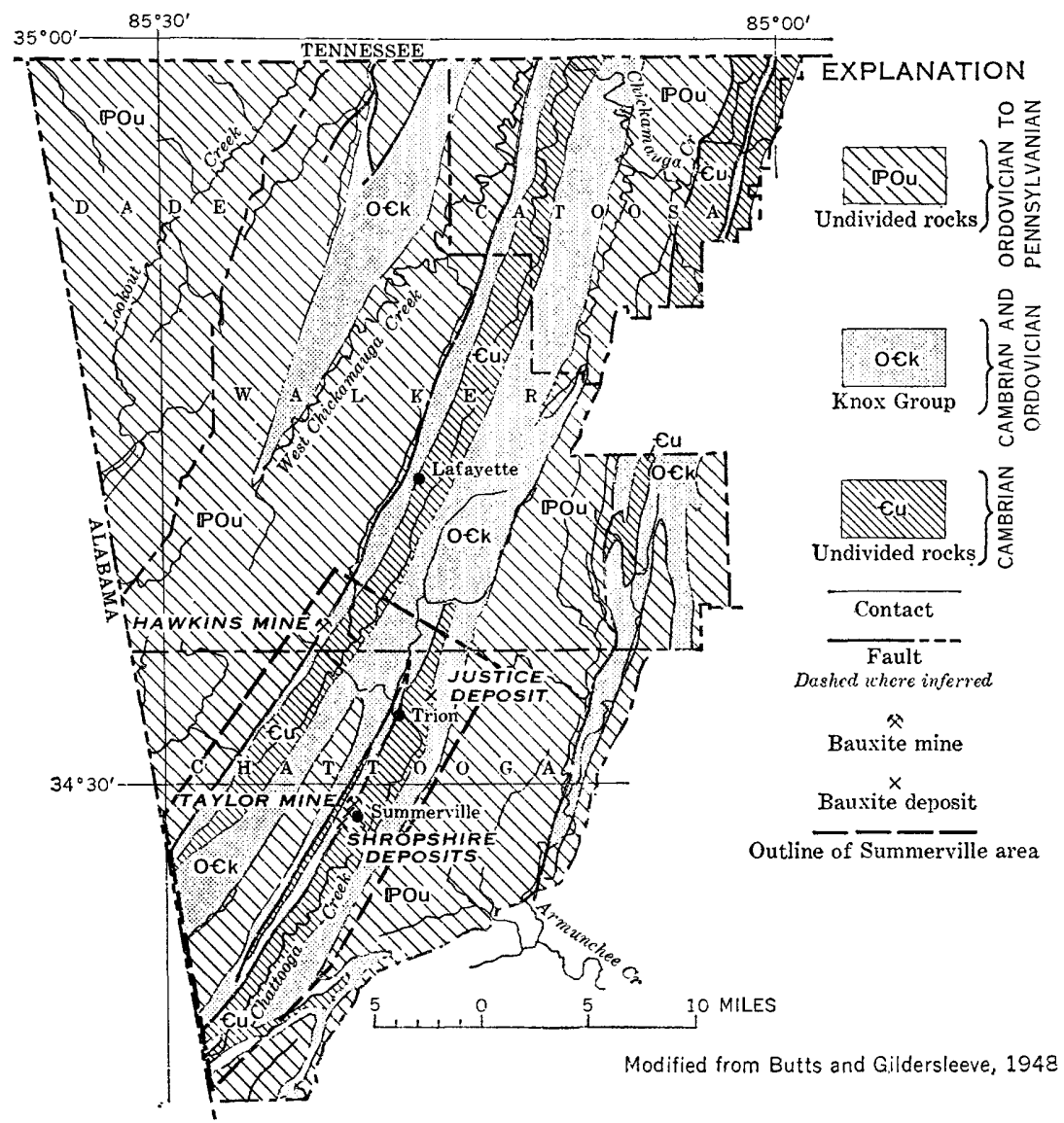

FrguRe 5.-Geologic map of the Summerville area and adjacent parts of Northwest Georgia, showing location of the bauxite deposits.

As shown in figure 5, four of the five deposits are close to major thrust faults. The fifth, the Justice deposit, is close to the contact between the Knox Group and older Cambrian rocks. The faults, by providing channels favorable for circulation of underground water, may have promoted formation of sinkholes in the Knox Group similar to those in which most of the bauxite deposits of Northwest Georgia are believed to have accumulated.

\section{BAUXITE DEPOSITS}

\section{TAYLOR MINE}

The John D. Taylor deposit, or Taylor mine, is the northeasternmost of the bauxite deposits at Summerville (fig. 6). The deposit, about 400 feet west of the Dry Valley Road, is in a small ravine about mid- 


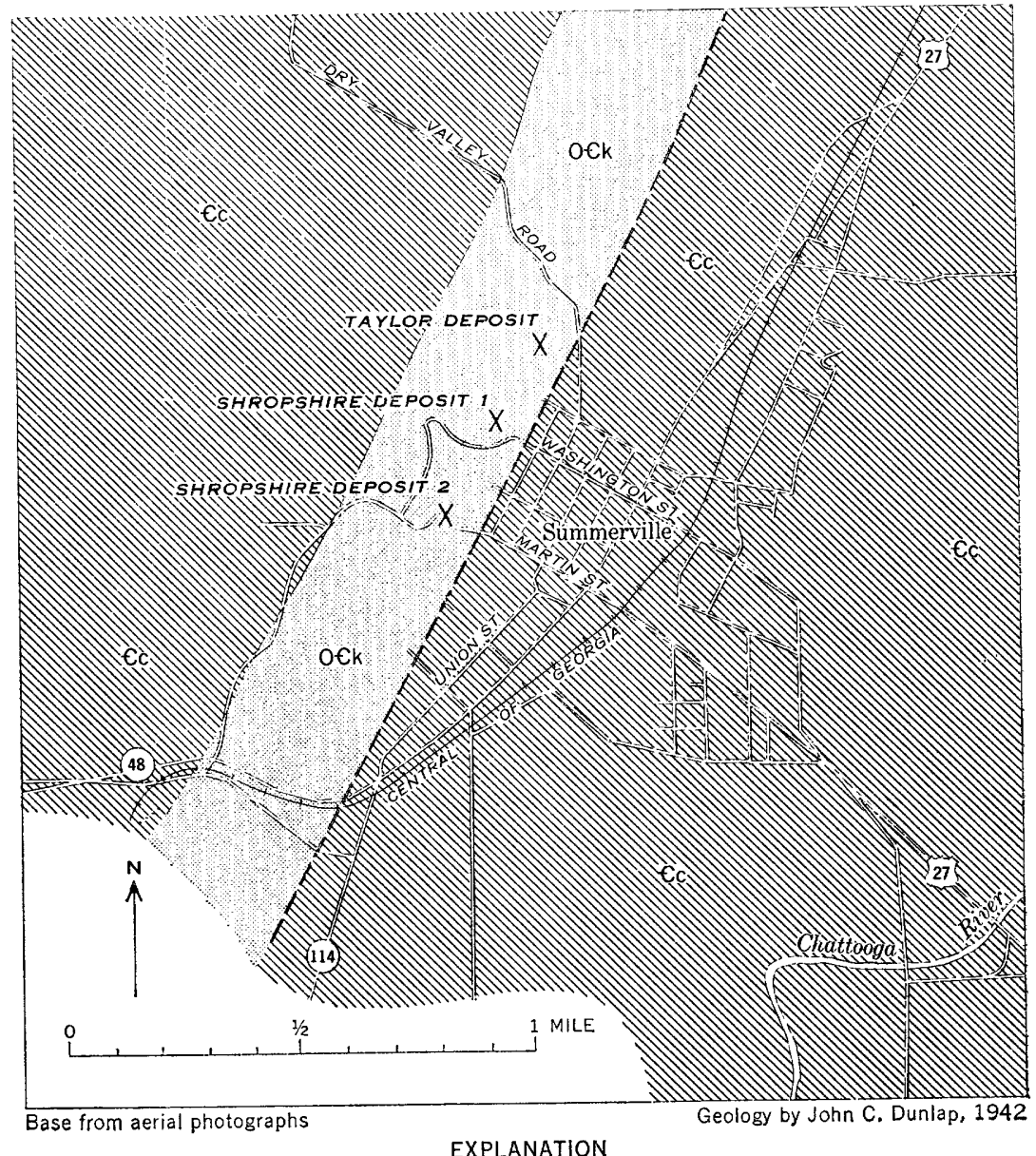

EXPLANATION

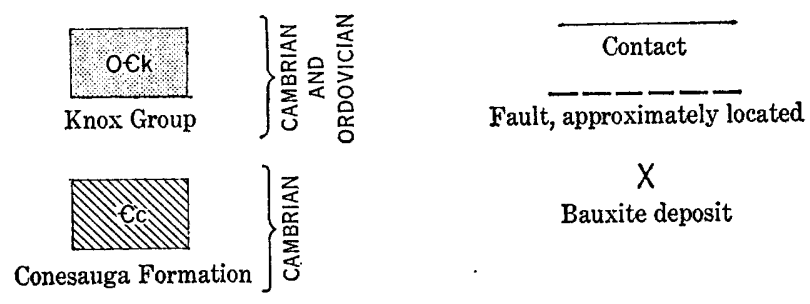

Frgore 6.-Location of bauxite deposits at Summerville, Ga.

way up the east-facing slope of a ridge that extends southwestward through the town. The altitude of the bottom of the pit is 769 feet, and the altitude at the top of the uphill side of the pit is 790 feet.

The deposit is on the east limb of an anticline and is underlain by the Copper Ridge Dolomite of the Knox Group (Upper Cambrian). No 
bedrock is exposed in the vicinity of the pit. At an exposure 0.2 mile northwest of the mine the strike is N. $24^{\circ} \mathrm{E}$., and the beds are vertical. If this structure extends to the pit, the bauxite deposit is about 800 feet stratigraphically above the base of the Copper Ridge Dolomite. A short distance to the east major faulting has thrust the Conasauga Formation (Middle and Upper Cambrian) onto the rocks of the Knox Group (fig. 6).

About 100 tons of pisolitic bauxite was reported shipped from the mine (Watson, 1904, p. 114). Probably all the ore was taken from the pit, as no bauxite can be seen in waste material taken from a tunnel.

The development work on the property, done by Mr. John D. Taylor, Sr., about 1900, consists of a large opencut about 90 feet long, 40 feet wide, and 20 feet deep; a shallow test pit about 25 feet long that is about 120 feet east of the main pit; and a caved tunnel, which extends for roughly 150 feet in a N. $35^{\circ}$ E. direction that is about 95 feet north of the pit. As the walls of all the workings have slumped and are largely covered with vegetation, detailed relations between the bauxite, bauxitic clay, residuum, and overburden are not apparent.

Where they are not covered, the walls of the trench forming the entrance to the main pit show white to orange sandy clay containing chert and a thin bed of impure limonite. The wall of the open pit on the uphill, or west side, exposes at least 6 feet of yellow to orange cherty sandy clay and red to cream, slightly sandy clay beneath it. The low walls to the northeast, south, and southwest expose 3 to 5 feet of chert-bearing red and orange sandy clay, underlain by white to red, blocky slickensided bauxitic clay containing sand grains. No dornicks of pisolitic bauxite can be seen in the bauxitic clay or in the bottom of the pit.

A sample of the bauxitic clay from the walls of the pit, analyzed at the U.S. Bureau of Mines laboratory, Tuscaloosa, Ala., contained 38.10 percent $\mathrm{Al}_{2} \mathrm{O}_{3}, 1.18$ percent $\mathrm{Fe}_{2} \mathrm{O}_{3}, 1.57$ percent $\mathrm{TiO}_{2}$, and 44.63 percent insoluble.

Scattered around the edges of the pit and on the dump are numerous boulders of hard, white to cream-colored, pisolitic bauxite which Watson (1904, p. 115) reported were in a matrix of massive blocky white bauxitic clay. The pisolitic ore that was being mined contained 51.56 percent $\mathrm{Al}_{2} \mathrm{O}_{3}, 2.40$ percent $\mathrm{Fe}_{2} \mathrm{O}_{3}, 4.40$ percent $\mathrm{TiO}_{2}, 3.35$ percent $\mathrm{SiO}_{2}$, and 32.20 percent loss on ignition (Watson, 1904).

The shape of the ore body is not known, but the deposit may extend both northeast and southwest of the pit and possibly to a greater depth than the present workings. Extension to the northeast, however, is limited by a deep valley that cuts through the ridge 450 feet from the present workings. 
The overburden, as observed in the walls of the pit, ranges from 3 to 6 feet in thickness and is yellow to red sandy clay containing chert fragments.

\section{SHROPSHIRE DEPOSIT 1}

The Shropshire deposit 1 is approximately 1,100 feet southwest of the Taylor mine and is at the end of Washington Street at the west edge of Summerville (fig. 6). It was formerly known as the Goddard property and is the more southern of the two ore bodies discussed by Watson (1904, p. 114) under the name of Taylor bank. No bauxite has been mined unless a wagon load or two was obtained from the test pits.

The deposit is in a shallow ravine near the base of the same slope as the Taylor deposit and is at the same altitude $(769 \mathrm{ft}$ ) as the base of the pit at the Taylor mine. The structural and stratigraphic position is the same for both deposits.

The original surface indication is not known, but most likely pisolitic material cropped out or was found as float on the surface. Two or three shallow depressions are all that remain of half a dozen or more prospect pits which constituted the only development. Boulders of hard, cream to red, pisolitic bauxite containing medium-sized pisolites lie on the ground in the vicinity of the shallow pits. Watson $(1904$, p. 114) reported some pebble ore near the top of several of the pits but stated that the predominant type was hard pisolitic bauxite which in places was highly ferruginous. The bauxite is associated with a pink and white mottled clay. A specimen of the pisolitic bauxite analyzed at the U.S. Bureau of Mines laboratory at Tuscaloosa, Ala., contained 57.67 percent $\mathrm{Al}_{2} \mathrm{O}_{3}, 6.35$ percent $\mathrm{Fe}_{2} \mathrm{O}_{3}, 2.68$ percent $\mathrm{TiO}_{2}$, and 2.22 percent insoluble.

The size and shape of the deposit are not known, but the best possibilities of extension are believed to be northeastward and southwestward along the regional strike of bedrock. The overburden is probably only 3 to 5 feet thick over the entire deposit and consists of gray to red sandy clay containing fragments of chert.

\section{SHROPSHIRE DEPOSI' 2}

The Shropshire deposit 2 is approximately 1,300 feet southwest along the strike from the Shropshire deposit 1. This is the property discussed by Watson (1904, p. 115-116) as Scruggs bank. The deposit is just west of the large chert pit on the north side of Martin Street (fig. 6). Only bauxitic clay was exposed in 1942 in a small excavation at the edge of the street.

The deposit is on the northeast side of a small valley on the east side of the same ridge as the two preceding deposits and at an altitude of 
725 feet. The structural and stratigraphic positions are the same as for the previously described deposits.

The bauxitic clay is white to red, blocky, and apparently contains considerably more sand than that in the Taylor pit. A 5-foot-thick bed of brown iron ore mixed with ferruginous clay and chert overlies the bauxitic clay and dips about $80^{\circ} \mathrm{SE}$. About 145 feet west of the deposit an old pit, now filled, is reported to have contained bauxite. It is probably one of the pits mentioned by Watson (1904, p. 115) who stated that half a dozen pits had been sunk in an area of approximately an acre and that the deepest of these was 40 feet deep. Some of the pits were in bauxite and bauxitic clay. Watson (1904, p. 115-116) also described the ore as being "an excellent grade of white pebble and gravel bauxite $* * *$ in a claylike matrix $* * *$ and averaging about 3 percent in silica and 1 percent in iron oxide." A sample of the clayey matrix analyzed at the U.S. Bureau of Mines laboratory at Tuscaloosa, Ala., contained 27.48 percent $\mathrm{Al}_{2} \mathrm{O}_{3}, 0.64$ percent $\mathrm{Fe}_{2} \mathrm{O}_{3}$, 1.88 percent $\mathrm{TiO}_{2}$, and 60.14 percent insoluble.

This deposit together with the two discussed above are alined almost exactly parallel to the regional strike of the bedrock. This similarity of geological environment, particularly the presence of the bed of limonite, which, according to Hayes (1895, p. 587), also dipped $80^{\circ}$ SE. at the Taylor pit, strongly suggests that additional occurrences of bauxite may be found along strike between the Taylor pit and the most southerly Shropshire property. A careful search of the surface of this area failed to disclose bauxite, but it might be obscured by wash from the slope above or by the heavy vegetation present over most of the area.

\section{JUSTICE DEPOSIT}

The Justice deposit is 1.8 miles N. $57^{\circ}$ E. of Trion and is on the eastfacing slope of the first ridge in the valley east of Trion. It is almost certainly the same deposit Watson (1904, p. 116) described as Trion Factory. Attention was probably first directed to the deposit by a conspicuous outcrop of siliceous limonite and ferruginous chert, together with a small amount of ferruginous pisolitic bauxite.

The deposit is in a shallow ravine on the ridge and is about twothirds of the distance up the slope. The altitude at the bottom of the lowest opening is 900 feet and at the upper opening is 918 feet, as determined by aneroid barometer.

Although no diagnostic fossils have been found and no bedrock is exposed in the vicinity of the prospect, it is most likely that this deposit is underlain by the Copper Ridge Dolomite of the Knox Group and is probably near the top of the formation. The bauxite and 
limonite may have accumulated along a fault within the Copper Ridge, but no evidence is available to prove this. The deposit is on the east limb of an anticline, at the center of which shale and limestone of the Conasauga Formation are exposed.

No bauxite has been mined from the deposit, and four shallow test pits and one trench are the only development. The walls of the test pits and trench have slumped and are covered with slope wash. Red sandy clay with fragments of ferruginous chert, siliceous brown iron concretions, and white chert can be seen in places in the walls. The overburden is red sandy and cherty clay about 3 to 6 feet thick.

The dump material taken from the test pits consists of boulders and fragments of hard red highly ferruginous pisolitic bauxite containing medium to large pisolites. In some boulders the bauxite is intimately mixed with limonite and highly ferruginous chert. Massive buff-colored material from the wall of the trench, analyzed at the U.S. Bureau of Mines laboratory in Tuscaloosa, Ala., contained 29.14 percent $\mathrm{A1}_{2} \mathrm{O}_{3}, 21.70$ percent $\mathrm{Fe}_{2} \mathrm{O}_{3}, 1.84$ percent $\mathrm{TiO}_{2}$, and 33.77 percent insoluble.

The size and shape of the deposit are not known. The test pits, all penetrating bauxite, are distributed over an area 90 feet long and 50 feet wide, in a northwesterly direction. The altitude ranges from 900 feet at the trench to about 918 feet at the most northwesterly pit. According to Mr. F. A. Justice, the test pits were dug by employees of Mr. John H. Hawkins in 1907. Float of brown iron ore occurs sparsely on the surface to the southwest, and the deposit may extend in that direction. Approximately 600 feet southwest of the deposit are three shafts, the deepest of which is reported to be 90 feet. Apparently no bauxite was penetrated in the shafts, as only brown iron ore and ferruginous chert appear on the surface around them. The bauxite at this deposit is too high in iron and too intimately mixed with brown iron ore and chert to have commercial value.

\section{HAWKINS MINE}

The Hawkins mine, 0.28 mile northeast of Hawkins Station of the Tennessee, Alabama and Georgia Railway Co., is in the southern part of Walker County approximately 8.5 miles southwest of the town of Lafayette. The deposit was originally called the Armington bank. The pit is about 1,000 feet due north of the county road and about 600 feet due east of the railroad tracks (fig. 7).

The mine is on the south-facing slope of a hill just north of a saddle in the main northeastward-trending ridge. The bottom of the main open pit is at an altitude of 831 feet; the altitude at the top of the north wall (highest part of mine) is 886 feet. 


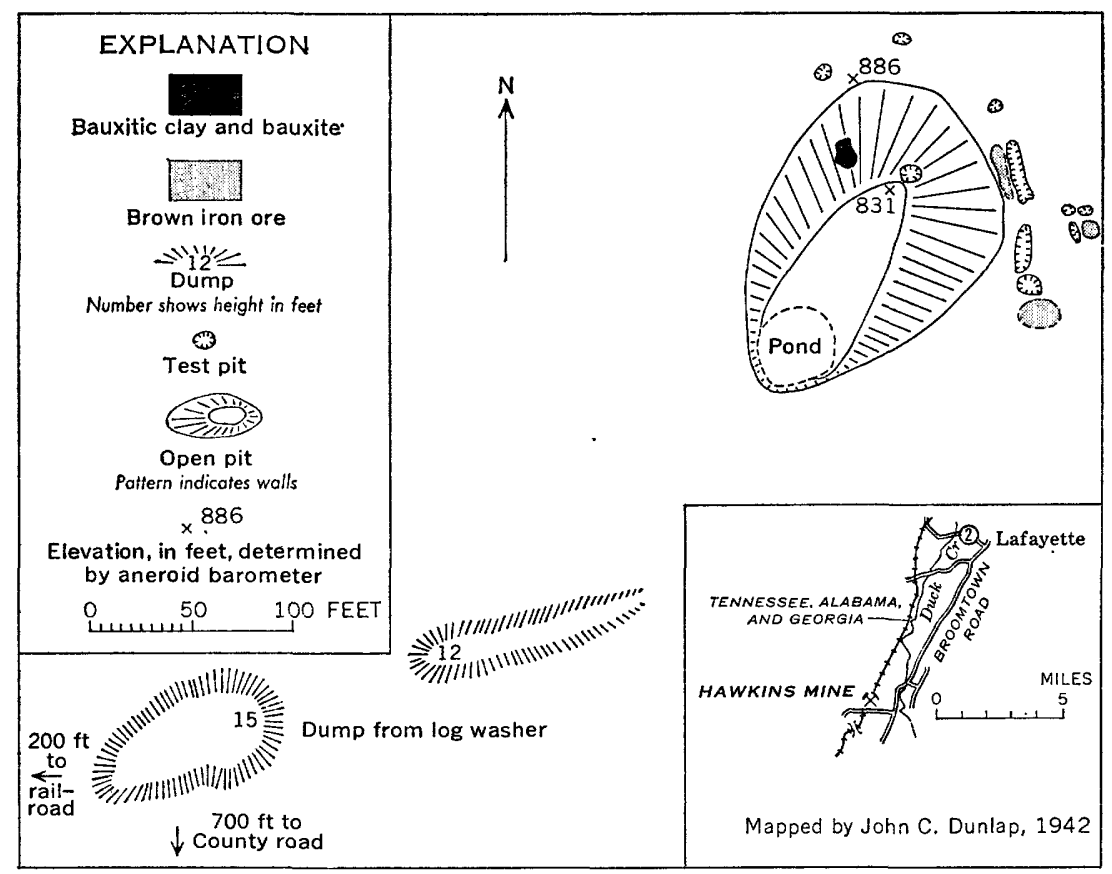

Figure 7.-The Hawkins mine, Walker County, Ga.

The deposit is on the west limb of a slightly overturned anticline. The stratigraphic position of the deposit is 200 to 300 feet below the top of the Knox Group. No bedrock is exposed in the pit, but an exposure of bedded chert at Hawkins Station, 0.28 mile to the southwest, strikes $\mathrm{N} .9^{\circ} \mathrm{E}$. and dips $72^{\circ} \mathrm{SE}$.

The Hawkins mine has had more development and has produced more bauxite than any other deposit in the Summerville area. The extent of the workings and test pits as of 1942 are shown on the sketch map, figure 7. The tonnage of bauxite mined here is not known, but it is reported that a profit of $\$ 35,000$ was realized with the ore selling for slightly more than $\$ 7.00$ per ton.

Pebble bauxite and dornicks of hard cream-colored bauxite containing pisolites of various sizes occur in the floor of the pit and are strewn about at the washing plant. The pisolites in some of the dornicks are red in color and crumble readily to a powder. The pebbles of bauxite range in size from less than half an inch to more than 2 inches in diameter. Watson $(1904$, p. 117) gave the results of analyses (in percent) of four samples of ore from this deposit as follows: 


\begin{tabular}{|c|c|c|c|c|}
\hline & 1 & 2 & 3 & 4 \\
\hline $\begin{array}{l}\mathrm{Al}_{2} \mathrm{O}_{3} \\
\mathrm{Fe}_{2} \mathrm{O}_{3} \\
\mathrm{TiO}_{2} \\
\mathrm{SiO}_{2} \\
\mathrm{H}_{2} \mathrm{O} \text { (combined) } \\
\mathrm{M} \text { oisture. }\end{array}$ & $\begin{array}{r}75.03 \\
1.84 \\
.96 \\
2.66 \\
16.00 \\
3.00\end{array}$ & $\begin{array}{r}60.00 \\
.65 \\
3.65 \\
.80 \\
35.00\end{array}$ & $\begin{array}{r}58.90 \\
1.20 \\
4.30 \\
1.40 \\
34.20\end{array}$ & $\begin{array}{r}60.83 \\
1.82 \\
3.90 \\
.85 \\
32.60\end{array}$ \\
\hline Total & 99.49 & 100.10 & 100.00 & 100.00 \\
\hline
\end{tabular}

The analyses given by Watson probably represent both pisolitic and pebble-type bauxite and indicate grade $\mathrm{A}$ bauxite by present methods of classification. Sample 1 was probably dried before chemical analysis because the total $\mathrm{H}_{2} \mathrm{O}$ amounts to only 19 percent.

The overburden of sandy cherty clay is about 3 feet thick. The outline of the "cup-shaped" main pit (fig. 7) probably coincides with that of the ore body, and because very little bauxitic material is on the dump, or in the pit walls, it is believed that the ore body has been mined out.

The walls of the pit are somewhat obscured by slope wash. The west wall and upper part of the north wall consists of red to white sandy clay containing chert and pockets of fine-grained white sand. White to purple sandy bauxitic clay containing fragments of pisolitic and pebble-type bauxite can be seen about midway up the north wall. The northeast and east walls show only white to red sandy clay with large amounts of chert.

At the time the deposit was mined, two pits near the north and northeast edges of the main pit (fig. 7) were dug to depths of 20 to 25 feet, and holes were then drilled from the pit bottoms to a depth of about 60 feet with a soil auger. No bauxite or bauxitic clay was found. A hole near the base of the northeast wall was drilled to find the bottom of the ore body. The trenches and pits near the east edge of the pit were dug in mining brown iron ore, a carload of which was shipped. No bauxite was present with the brown ore. A number of auger holes around the south and west edges of the pit and at other places on the hill were drilled by Mr. Hawkins to a depth of 20 feet. No bauxite was found.

\section{REFERENCES CITED}

Adams, G. I., 1923, The formation of bauxite in sinkholes: Econ. Geology, v. 18, no. 4, p. 410-412.

Bridge, Josiah, 1950, Bauxite deposits of the Southeastern United States in Snyder, F. G., Symposium on mineral resources of the Southeastern United States; Knoxville, Tenn., Univ. Tennessee Press, p. 170-201. 
Butts, Charles, and Gildersleeve, Benjamin, 1948, Geology and mineral resources of the Paleozoic area in northwest Georgia: Georgia Geol. Survey Bull. 54, $176 \mathrm{p}$.

Cloud, P. E., Jr., and Brown, R. W., 1944, Early Cenozoic sediments in the Appalachian region [abs.] : Geol. Soc. America Bull., v. 55, no. 12, p. 1466.

Franke, H. A., and Trought, M. E., 1939, Bauxite and aluminum : U.S. Bur. Mines Minerals Yearbook, 1939, p. 633-653.

Hayes, C. W., 1895, Bauxite, its occurrence, geology, origin, and economic value : U.S. Geol. Survey 16th Ann. Rept., pt. 3, p. 547-597.

1902, Description of the Rome quadrangle [Georgia-Alabama] : U.S. Geol. Survey Geol. Atlas, Folio 78, 6 p.

Hill, J. M., 1921, Bauxite and aluminum: U.S. Geol. Survey Mineral Resources U.S., 1917, p. 1-9.

Ingalls, W. R., ed., 1906, Bauxite in Mineral Industry, during 1905: New York, Eng. and Mining Jour. Press, v. 14, p. 46-51.

Julihn, C. E., 1933, Bauxite and aluminum: U.S. Bur. Mines Mineral Resources U.S. 1930, pt. 1, p. 151-178.

Lewiecki, W. T., 1949, Investigation of the Hermitage bauxite district, Bartow and Floyd Counties, Georgia: U.S. Bur. Mines Rept. Inv. 4577, 10 p.

McCallie, S. W., 1910, A preliminary report on the mineral resources of Georgia : Georgia Geol. Survey Bull. 23, 208 p.

Morse, P. F., 1923, The bauxite deposits of Mississippi : Mississippi Geol. Survey Bull. 19, $208 \mathrm{p}$.

Overstreet, E. F., 1964, Geology of the Southeastern bauxite deposits : U.S. Geol. Survey Bull. 1199-A, 19 p.

Phalen, W. C., 1911, Bauxite and aluminum : U.S. Geol. Survey Mineral Resources U.S., 1910, pt. 1, p. 711-723.

1916, Bauxite and aluminum: U.S. Geol. Survey Mineral Resources U.S., 1914, pt. 1, p. 183-209.

Shearer, H. K., 1917, Notes on the bauxite deposits of north Georgia, Appendix $B$ in A report on the bauxite and fuller's earth of the Coastal Plain of Georgia : Georgia Geol. Survey Bull. 31, p. 325-329.

Spencer, J. W., 1893, The Paleozoic group. The geology of ten counties of northwestern Georgia : Georgia Geol. Survey, 406 p., map.

Veatch, J. Otto, 1909, Second report on the clay deposits of Georgia: Georgia Geol. Survey Bull. 18, 453 p.

Watson, T. L., 1904, A preliminary report on the bauxite deposits of Georgia: Georgia Geol. Survey Bull. 11, $169 \mathrm{p}$.

White, W. S., and Denson, N. M., 1952, The bauxite deposits of Floyd, Bartow, and Polk Counties, northwest Georgia: U.S. Geol. Survey Circ. 193, 27 p. 

